1 This manuscript has been submitted for publication in GEOMORPHOLOGY. Please note that, despite having undergone peer-

2 review, the manuscript has yet to be formally accepted for publication. Subsequent versions of this manuscript may have slightly

3 different content. If accepted, the final version of this manuscript will be available via the 'Peer-reviewed Publication DOI' link on the 4 right-hand side of this webpage. Please feel free to contact any of the authors; we welcome feedback. 


\title{
Modeling the spatial dynamics of marsh ponds in New England salt marshes
}

G. Mariotti ${ }^{1,2}$, A.C. Spivak ${ }^{3}$, S.Y. Luk ${ }^{4}$, G. Ceccherini ${ }^{5}$, M. Tyrrell ${ }^{6}$, M. Eagle Gonneea ${ }^{7}$

1. Louisiana State University, Department of Oceanography and Coastal Sciences, Baton Rouge (LA), USA

2. Louisiana State University, Center for Computation and Technology, Baton Rouge (LA), USA

3. University of Georgia, Department of Marine Sciences, Athens (GA), USA

4. Woods Hole Oceanographic Institution, Department of Marine Chemistry and Geochemistry, Woods Hole (MA), USA

5. Joint Research Centre, Bioeconomy Unit, European Commission, Ispra, Italy

6. Waquoit Bay National Estuarine Research Reserve, Falmouth (MA), USA

7. U.S. Geological Survey, Woods Hole (MA), USA

1

\begin{abstract}
Ponds are common features on salt marshes, yet it is unclear how they affect large-scale marsh evolution. We developed a spatially explicit model that combines cellular automata for pond formation, expansion, and drainage, and partial differential equations for elevation dynamics. We use the mesotidal Barnstable marsh (MA, USA) as a case study, for which we measured pond expansion rate by remote sensing analysis over a 41-year time span. We estimated pond formation rate by comparing observed and modeled pond size distribution, and predicted pond deepening by comparing modeled and measured pond depth. The Barnstable marsh is currently in the pond recovery regime, i.e., every pond revegetates and recovers
\end{abstract}


31 the necessary elevation to support plant growth after re-connecting to the channel network. This pond 32 dynamic creates an equivalent (i.e., spatially and temporally averaged over the whole marsh) $0.5-2 \mathrm{~mm} / \mathrm{yr}$ 33 elevation loss that needs to be supplemented by excess vertical accretion. We explore how the pond 34 regime would change with decreased sediment supply and increased relative sea-level rise (RSLR) rate, 35 focusing on the case in which the vegetated marsh keeps pace with RSLR. When the RSLR rate remains 36 below the minimum unvegetated deposition rate, the pond dynamics is nearly unaltered and ponds always 37 occupy $\sim 10 \%$ of the marsh area. However, when RSLR rate exceeds this threshold, the ponds in the 38 marsh interior - which receive the least amount of suspended sediment - do not recover after drainage. 39 These ponds transition to mudflats and permanently occupy up to $30 \%$ of the marsh area depending on 40 RSLR rate. For marshes with a small tidal range, such as the microtidal Sage Lot Pond marsh on the 41 opposite side of the peninsula from Barnstable marsh, high RSLR rates could bring every portion of the 42 marsh into the pond runaway regime, with the whole marsh eventually converting into mudflats. In this 43 regime, the existing marsh would disappear within centuries to millennia depending on the RSLR rate. 44 Because of the spatial and temporal components of marsh evolution, a single RSLR threshold value 45 applied across the entire marsh landscape provides a limited description of the marsh vulnerability to RSLR. 


\section{Introduction}

52 Marsh evolution models commonly assume a homogenous marsh platform, in which both elevation and

53 plant biomass change smoothly except close to a few ecotones (Marani et al., 2013). On the contrary,

54 many marsh platforms are highly heterogeneous because of the presence of ponds - semicircular

55 depressions permanently inundated even at low tide. This heterogeneity is particularly relevant for the

56 Mid-Atlantic and New England coast of the USA, where ponds are ubiquitous features (Adamowicz and

57 Roman, 2005; Harshberger, 1909; Koop-Jakobsen and Gutbrod, 2019; Redfield, 1972; Schepers et al.,

58 2017). Thus, considering the presence of ponds is necessary to accurately predict the landscape-level

59 evolution and persistence of these salt marshes under climate change.

60 Ponds haven been simulated in a simplified 2D model (Kirwan et al., 2008) by lowering the elevation and

61 preventing vegetation growth in a few random locations on the marsh platform. After this temporary

62 disturbance, the vegetation was allowed to regrow and the bed quickly regained its original elevation by

63 accreting faster than RSLR rate. Because of these localized and temporary bursts of vertical accretion, the

64 model provided a simple explanation for the presence of spatial heterogeneities in marsh vertical

65 accretion and for the widely observed mismatch between marsh vertical accretion and RSLR.

66 Nonetheless, the model overlooked several physically-based processes that play a key role in pond

67 dynamics: pond deepening by organic matter oxidation, pond expansion by erosion of the pond edge, and

68 pond drainage by channel interception.

69 A simple lumped model that considered the evolution of a single pond (Mariotti, 2016) suggested that

70 marshes are either in a regime of pond recovery where ponds form, expand, reconnect with the nearby

71 tidal creek and recover to the surrounding marsh elevation, or in a regime of pond runaway (also called

72 pond collapse regime) in which ponds do not revegetate and marsh area is lost even if the vegetated

73 platform keeps pace with sea-level rise. Vertical accretion by in situ plant production does not contribute

74 to pond recovery if, at the time of pond drainage, the elevation of the pond bed is below the limit for

75 vegetation growth, which is roughly equal to mean sea level along the Atlantic and Gulf Coast of the 
USA (McKee and Patrick, 1988). Indeed, if the bed elevation lies below the limit for vegetation growth,

77 vertical accretion is only provided by deposition of suspended sediment. Vertical accretion by in situ plant

78 production would be present only after the elevation deficit for vegetation growth is overcome.

79 Accordingly, the model found that the marsh enters the pond runaway regime when the RSLR rate is

80 larger than the minimum unvegetated accretion rate (Mariotti, 2016), which is equal to $C \cdot r /\left(2 T \cdot \rho_{m}\right)$, where

$81 C$ is the suspended sediment concentration, $r$ is the tidal range, $T$ is the tidal period, and $\rho_{m}$ is the mud dry

82 bulk density. Marshes are thus more likely to be in the pond runaway regime if the tidal range is small,

83 but a very large sediment supply can allow for pond recovery in microtidal systems, as shown by an

84 example in coastal Louisiana (Mariotti, 2016). A major limitation of the model, however, was that it

85 neglected the interactions between multiple ponds, which likely represent important spatial dynamics over

86 long time scales. As a consequence, the model was not able to predict spatially averaged metrics, such as

87 the amount of pond area on the marsh platform in the pond recovery regime or the rate of pond area increase in the pond runaway regime.

89 When considering the dynamics of ponds, it is also important to simulate key aspects of sediment transport. For example, it is crucial to simulate how the suspended sediment concentration (SSC) that

91 drives inorganic deposition (i.e., mud) varies in space, such as the SSC decreases with distance from the

92 channels (Christiansen et al., 2000; Fagherazzi et al., 2012), thus making the marsh interior more

93 susceptible to entering the pond runaway regime. In addition, lateral sediment redistribution by soil

94 diffusion (or soil creep), which is present along marsh boundaries with sharp elevation gradients such as

95 the banks tidal creeks (Kirwan and Murray, 2007; Mariotti, 2018; Mariotti et al., 2019, 2016), could

96 transfer sediment from high to low elevation areas and thus affect the rate of vertical elevation change.

97 Another important aspect to consider is the biogeochemical dynamics of ponds. The emergent vegetation 98 that dominates the marsh platform (e.g., Spartina alterniflora, S. patens, Distichlis spicata, etc.) cannot 99 survive in ponds because of inundation stress or because of the high salinity that results from the absence 100 of regular flushing (Pethick, 1974). Instead, ponds in New England marshes are colonized by 
communities of micro- and macro-algae and submerged grasses such as Ruppia maritima (Harshberger, 1909; Spivak et al., 2017). The organic matter composition of pond surface sediments reflects inputs from algal and plant communities that colonize ponds during formation (Spivak et al., 2018). Yet, the contribution of submerged algae and grasses to vertical accretion in ponds is likely negligible, given that ponds tend to be net heterotrophic (Spivak et al., 2017) and thus do not accumulate carbon but rather 106 remove the existing one.

107 In addition to the absence of vertical accretion, ponds might actually experience a net elevation loss. 108 Indeed, the high rates of respiration, driven primarily by sulfate reduction (van Huissteden and van de 109 Plassche 1998), convert buried organic matter into dissolved inorganic carbon and thereby contribute to 110 soil column collapse and pond deepening (Johnston et al., 2003; Spivak et al., 2018, 2017). The elevation 111 trajectory of ponds is thus diametrically opposite to that of the marsh platform, which gains elevation 112 through time via suspended sediment deposition and in situ plant production. As a result, ponds in New 113 England marshes are likely experiencing a gradual deepening with respect to the surrounding marsh 114 platform (Wilson et al., 2009, 2010).

115 Here, we develop a spatially explicit model for pond dynamics. We apply the model to the Barnstable 116 marsh (MA, USA), which is a typical mesotidal marsh in New England, and constrain the model with

117 field data and remote sensing analysis. We also consider the case with a smaller tidal range, using as 118 reference a nearby microtidal marsh with limited sediment supply (the Sage Lot Pond marsh). Then, we 119 explore the model for different RSLR rates and sediment supply to predict future marsh trajectories. As 120 suggested by a previous idealized model (Mariotti, 2016), we expect to find a threshold above which 121 ponds never revegetate and thus lead to permanent marsh loss. By including pond dynamics within the 122 model, we predict marsh loss when the marsh complex enters the runaway pond regime, which occurs 123 even when deposition on the vegetated marsh platform is equal or greater than the RSLR rate, a 124 commonly used threshold for marsh drowning (Morris et al., 2002).

\section{2. Site description}


The study area is in the New England region of the United States, which experiences a temperate climate,

127 about $1000 \mathrm{~mm}$ of precipitation per year, a growing season from May to September, and overnight freezes

128 during the winter (Mariotti et al., 2019). Ice rafting has been documented to occur, especially in

129 concomitance with winter storm surges (Argow et al., 2011).

130 Barnstable is a mesotidal backbarrier marsh, located on the north side of the Cape Cod peninsula (Fig. 1).

131 The spring tidal range is about $3.6 \mathrm{~m}$ (NOAA Sesuit Harbor station 8447241). The marsh is dominated by

132 S. alterniflora in the low marsh and S. patens in the high marsh (Redfield, 1972). The majority of the

133 Barnstable marsh has been ditched since the early 1900s. For simplicity, in this study we focus on an area

134 that does not have man-made ditches (Fig. 1). This choice allows us to isolate and understand the spatially

135 explicit pond dynamics under natural conditions, without the confounding effects of mechanical

136 anthropogenic disturbances.

137 Sage Lot Pond is a polyhaline, microtidal (0.7 m spring tidal range, NOAA Woods Hole Station 8447930)

138 backbarrier marsh located on the south side of the Cape Cod peninsula (Fig. 1). The marsh is dominated

139 by short form S. alterniflora on the low marsh and Distichilis spicata, Juncus gerardii, and some $S$.

140 patens at higher elevations (Gonneea et al. 2019). This marsh is also ditched.

141 According to the nearby NOAA station 8443970, mean sea level was $-9.2 \mathrm{~cm}$ in the NAVD88 datum

142 during the epoch 1983-2001. Considering the recent increase in sea level, we assume that MSL is now at

$1430 \mathrm{~m}$ NAVD88, which agrees with the datum analysis in the nearby Plum Island Estuary marsh

144 (Hopkinson et al., 2018).

145 3. Methods

$146 \quad 3.1$ Field measurements and remote sensing analysis

147 For the Barnstable marsh, suspended sediments in tidal creek water were collected in triplicate 1-liter pre-

148 combusted $\left(450^{\circ} \mathrm{C}\right)$ glass bottles from four different locations (Fig. 1) between June $21^{\text {st }}$ and August $1^{\text {st }}$

149 2018. All samples were collected during the incoming tide. Samples were filtered through pre-combusted

150 and pre-weighed glass fiber filters (nominal pore size $0.45 \mu \mathrm{m}$ ). The filters were then dried to constant 
mass $\left(60^{\circ} \mathrm{C}\right)$ and concentrations were calculated by normalizing suspended sediment mass to the volume

152 filtered. While this sampling is not a comprehensive characterization of the sediment dynamics, it

153 provides at least a magnitude estimate, which is often the only data available (Cavatorta et al., 2003).

154 Sediment cores were collected from three transects at approximately $2 \mathrm{~m}$ (channel adjacent) and $100 \mathrm{~m}$

155 (marsh interior) from the creek bank (Table 1). All cores were taken in the vegetated platform, i.e., not in

156 a pond. Cores were collected with a modified piston core where a plastic core liner $(11 \mathrm{~cm}$ diameter $)$ was

157 fitted with a gasketed piston and placed on the sediment surface. The core liner was pushed $\sim 70 \mathrm{~cm}$ into

158 the marsh subsurface while the piston was maintained at the surface to minimize compaction, which was

159 observed through the clear core liner. The cores were split vertically, sampled at $1 \mathrm{~cm}$ intervals to $45 \mathrm{~cm}$

160 below soil surface and $2 \mathrm{~cm}$ intervals thereafter, frozen, and then freeze-dried. Sediment samples were

161 prepared for gamma analysis by sealing approximately $5 \mathrm{~g}$ of dried, homogenized peat for 3 weeks, and

162 counting on a planar-type gamma counter for 24 to 48 hours to measure ${ }^{7} \mathrm{Be},{ }^{137} \mathrm{Cs},{ }^{210} \mathrm{~Pb}$, and ${ }^{226} \mathrm{Ra}$ at

$163477,661.6,46.5$ and $352 \mathrm{KeV}$ energies respectively (Canberra Inc., USA). Detector efficiency was

164 determined from EPA standard pitchblende ore in the same geometry as the samples. Activities of ${ }^{7} \mathrm{Be}$,

$165{ }^{137} \mathrm{Cs}$, and ${ }^{210} \mathrm{~Pb}$ were decay corrected to time of collection. Suppression of low energy peaks by self-

166 adsorption was corrected for according to (Cutshall et al., 1983). Excess ${ }^{210} \mathrm{~Pb}$ was calculated by

167 subtracting supported ${ }^{226} \mathrm{Ra}$ from total ${ }^{210} \mathrm{~Pb}$ with a detection limit of $0.1 \mathrm{dpm} \mathrm{g}^{-1}$. Sediment ages were

168 calculated using the continuous rate of supply ${ }^{210} \mathrm{~Pb}$ age model, a variant on the advection-decay equation

169 (Appleby and Oldfield, 1978). This age model assumes that ${ }^{210} \mathrm{~Pb}$ down-core activity is a function of

170 decay and variable sediment accretion, however, the full ${ }^{210} \mathrm{~Pb}$ profile must be captured to prevent bias

171 towards ages that are too old and accretion rates that are too low at depth (Binford, 1990). Vertical

172 accretion rates were calculated as the age difference between each interval, with temporal resolution

173 typically 2 to 10 years depending on marsh, treatment, and sediment age.

174 Ponds within a few hundred meters from the sites where cores were collected were surveyed in the

175 summer of 2019 in one of two ways (Fig. 1G). First, 200 marsh-pond boundaries were surveyed in 2019 
176 by measuring the elevation of the marsh adjacent to the pond edge and the elevation of the pond bed 177 adjacent to the pond edge using an RTK-GPS with vertical accuracy of $2 \mathrm{~cm}$. The height of the pond bank 178 was calculated as the difference between these measurements. Second, elevation transects running 179 through the diameter of the pond were surveyed for thirteen of the 200 ponds (five small, five medium, 180 and three large ponds). The absolute bed elevation was referenced to the elevation of the adjacent marsh 181 surface, which was surveyed with the RTK-GPS.

182 We performed a remote sensing analysis using two datasets: USGS Single Frames Aerial Photos from 183 March 1973 with resolution of $\sim 0.5 \mathrm{~m}$ and USGS high resolution orthoimages from April 2014 with 184 resolution of $0.075 \mathrm{~m}$, both of which were collected at low tide (earthexplorer.gov). We also used USGS 185 Lidar collected in 2014 with resolution of $1 \mathrm{~m}$ (OCM Partners, 2019). For consistency we resampled all 186 datasets to a $1 \mathrm{~m}$ resolution. In both images we defined isolated ponds as those cells with standing water 187 at low tide, which were easily identifiable using a threshold on the intensity of the visible band. Pond 188 cells were clustered together using a five-point stencil connection, such that pond cells that touched each 189 other either on the top, bottom, right, or left boundary were grouped together. Then, we identified the 190 same ponds in each image and calculated the rate of area change. We excluded from the analysis those 191 ponds that either merged together or reconnected to the channel network between 1973 and 2014. From 192 the rate of area change, we calculated the equivalent rate of pond radius expansion. Change was measured 193 as a difference in area rather than the retreat of the pond edge, eliminating any error due to image 194 misalignment.

195 For the Sage Lot Pond marsh, SSC was measured from 2011 to 2018 across all seasons and tides. A total 196 of 258 grab samples $\left(500 \mathrm{~mL}\right.$ each) were collected and stored at $4{ }^{\circ} \mathrm{C}$ for a maximum of 1 week and then 197 filtered through pre-combusted borosilicate glass fiber filters ( 0.7 um pore size), rinsed thoroughly with 198 deionized water to remove salts, and dried at $105^{\circ} \mathrm{C}$ for $>4 \mathrm{~h}$. SSC was determined as the ratio of dried 199 filtrate mass total per sample volume. Existing vertical accretion measurements for Sage Lot Pond marsh 200 (Gonneea et al., 2019, 2018) are also reported in Table 1. 


\subsection{Model for pond dynamics}

202 Within the model, the pond dynamics is implemented as a cellular automata, in which each cell is 203 described by its state (which can only take a finite number of values) without explicitly simulating the 204 elevation. Channels are special cells that are fixed in time, which do not widen, narrow, or migrate

205 laterally. These cells don't take part in the evolution of the cellular automata and are collectively defined

206 as "channel network". Cells that are not part of the channel network are marsh cells, which collectively

207 constitute the marsh domain. Marsh cells are either connected or isolated. Connected cells experience 208 tidal fluctuations, and are defined as vegetated platform if their elevation is above the lower limit for 209 vegetation growth $\left(z_{\min }\right)$ or mudflat if their elevation is below $\left(z_{\min }\right)$. Isolated cells, also called isolated 210 ponds or ponds, do not experience tidal fluctuations or exchange with the channel network. Pond cells 211 with an elevation below $z_{\min }$ are defined as drowned ponds (Fig. 2).

212 Two processes allow for connected marsh cells to become isolated cells: pond formation and pond 213 expansion. In the real marsh, formation of new ponds can take place by a variety of mechanisms. A slight 214 depression in the marsh might lead to water logging and rapid decay of the marsh peat. Deposition of rafts 215 composed of either eroded plant material or macroalgae might kill the standing vegetation and 216 temporarily prevent new plant growth (Pethick, 1974). Ice rafting might compress the marsh (Argow and 217 FitzGerald, 2006) or remove large pieces of standing vegetation. Sub-surface piping might collapse the 218 marsh from below (Kesel and Smith, 1978). Large patches of vegetation can be removed by grazers such 219 a geese herbivory (Kirwan et al., 2008) and major storms (Howes et al., 2010). Rather than explicitly 220 modeling these different mechanisms, we simply assume that individual ponds form at a constant rate $k_{\text {seed }}$ 221 [\#ponds $\left./ \mathrm{m}^{2} / \mathrm{yr}\right]$, that is, during each time step $\Delta t$, each vegetated marsh cell is transformed into a pond cell 222 with a probability $k_{\text {seed }} \Delta t \Delta x^{2}$. Pond expansion allows existing ponds (i.e., clusters of connected pond cells) 223 to enlarge. This process is implemented at every boundary between a pond cell and a vegetated cell.

224 Expansion is simulated using a probabilistic approach (Mariotti and Canestrelli, 2017), in which a 
vegetated cell adjacent to a pond cell is converted to a pond cell with a probability $p=k_{\exp } \Delta t / \Delta x$, where $k_{\exp }$

226 is the expansion rate $[\mathrm{m} / \mathrm{yr}]$.

227 Pond cells transform into vegetated cells though pond drainage. In the real marsh, pond drainage occurs

228 when a pond become close enough to the channel network that a new connecting channel forms, as

229 exemplified in Fig. 1E. Then, the pond fills in quickly (assuming that there is enough sediment supply)

230 and the connecting channel, now lacking the tidal prism associated with the pond, eventually silts in. The

231 model is unable to explicitly simulate the formation or closure of these transient connecting channels,

232 since the model does not simulate tidal hydrodynamics and the main channel network is assumed to be

233 fixed in time. We thus parameterize this effect by assuming that pond drainage instantaneously occurs

234 when a connected cell becomes closer than a critical distance $L$ from the channel network. When this

235 happens, the whole pond, which consists of all pond cells that are contiguous to at least one pond cell

236 with distance $L$ from the channel network, are drained and all its cells become connected cells. The

237 distance $L$ is the distance at which the pressure gradient generated by the water in the pond is able to start

238 scouring the marsh soil - possibly by seepage and piping first - and eventually form a connecting

239 channel. In theory this distance might be calculated using a hydrodynamic and sediment transport model,

240 but for simplicity this distance is calibrated to reproduce the observation that ponds tend to drain when

241 they get about $20 \mathrm{~m}$ away from the main channel network (Fig. 1E).

\section{$242 \quad 3.3$ Model for elevation dynamics}

243 The elevation of each marsh cell relative to mean sea level, $z(x, y, t)$, is described as

$$
\frac{\mathrm{d} z}{\mathrm{~d} t}=D_{p}+D_{m}-S-P-R \quad(\text { Eq. } 1)
$$

245 where $D_{p}$ is the in situ organic accretion by marsh plants, $D_{m}$ is the accretion from suspended sediment,

246 which we assume is composed of mud and thus transported in suspension, $S$ is the divergence of the creep

247 flux $F, P$ is the elevation loss by pond dynamics (which is further explained below), and $R$ is the relative 248 sea-level rise rate. 
The organic accretion by in situ plant production is $D_{p}=D_{p M A X} B$, where $D_{p M A X}$ is the maximum accretion rate $[\mathrm{mm} / \mathrm{yr}]$ and $B$ is a function that describes the dependence on the bed elevation and serves as a proxy

251 for the hydroperiod, $B=\max \left[0,4\left(z-z_{\min }\right)\left(z_{\max }-z\right) /\left(z_{\max }-z_{\min }\right)^{2}\right]$, where $z_{\min }$ and $z_{\max }$ are the

252 minimum and maximum elevation for vegetation growth. $B$ is set equal to zero in isolated ponds,

253 simulating the absence of marsh plants and assuming that any macrophytes and microphytobenthos

254 present in ponds do not contribute to substantial vertical accretion.

255 Mud accretion depends on hydroperiod and the local SSC. The spatial pattern of SSC is described by

$$
C=C_{o}\left(\alpha+(1-\alpha) e^{-\beta l}\right)
$$

where $C_{o}$ is the time-average suspended sediment concentration in the channels, $l(x, y)$ is the distance to the closest cells that belong to the channel network, $\beta$ is the decay factor for SSC with distance from the channel network, and $\alpha$ is the factor describing the SSC that is spatially uniform. This last parameter allows transport of sediment even to large distances from the channels, and thus can parameterize processes such as storm-induced deposition on the marsh platform. Mud accretion thus equals

$$
D_{m}=\frac{C \min (h, r) \min (1, h / \Delta r)}{T \rho_{m}}
$$

where $h$ is the depth with respect to MHHW, $T$ is the tidal period, $\rho_{m}$ is the dry bulk density of the mud, and $\Delta r$ is the difference between the spring and neap high tide. The last factor in the numerator is introduced to account for modulation introduced by the spring-neap variability. If the marsh elevation is at least $\Delta r$ lower than MHHW, the marsh is inundated every tidal cycle and this factor is equal to one. If

267 the marsh is higher than this elevation, the marsh is only inundated during spring tides, and the factor will

268 be less than one. This allows mud to deposit at high marsh elevations but at a lower rate.

269 In theory, ponds could accrete vertically by suspended sediment deposition akin to the marsh platform.

270 Yet, several reasons suggest that this deposition is small. First, despite ponds having a large depth, the 271 water in the pond is not exchanged during tides. Only the thin layer of water that flows over the pond 
272 should count toward sediment deposition as formulated in Eq. 3 (which assumes that the water depth is

273 equal to the depth of the flow that floods that cell). Second, ponds lack the emergent marsh vegetation

274 that enhances sediment trapping. As a consequence, for the same water depth and sediment concentration,

275 a vegetated pond should experience a lower sediment deposition that a vegetated marsh. Third, ponds are

276 generally far from channels, specifically they are always farther than the distance $L$. As such, the

277 suspended sediment concentration above ponds is always lower than on the marsh close to the channel

278 edge. Furthermore, field data suggested that ponds in a New England salt marsh are isolated from the tidal

279 network and do not import sediment (Spivak et al., 2017). Overall, sediment deposition in the ponds is

280 likely very small, and for simplicity is set equal to zero.

281 The creep flux $F$ parameterizes all processes that cause soil diffusion and is set equal to $\mu \nabla z$, where $\mu$ is

282 the soil diffusivity coefficient, whose value was empirically found equal to $\sim 0.1 \mathrm{~m}^{2} / \mathrm{yr}$ (Mariotti et al.,

283 2019). The creep flux is set equal to zero within ponds and, more importantly, at the pond edges. This

284 choice reflects the absence of tidal oscillations, a process that creates "tidal fatigue" and is responsible for

285 the fast creep in channel banks (Mariotti et al., 2019). This is due to the standing water in the isolated

286 ponds maintaining hydrostatic pressure on the pond bank and preventing slumping during low tide. Thus,

287 the model allows isolated ponds to have relatively steep banks, as observed in the field (Wilson et al.,

288 2010). When pond cells reconnect, they drain instantaneously, and creep can take place. Excluding the

289 creep process at the edge of isolated ponds results in isolated pond expansion only occurring according to

290 the pond expansion term $k_{\text {exp }}$, which can be calibrated by direct comparison with the observed historical

291 expansion rate of isolated ponds. To summarize, creep does not affect isolated pond dynamics, but does

292 affect the dynamics of mudflats (i.e., connected ponds) and prevents the formation of an unrealistically

293 large elevation gradient in the marsh interior, which in reality might have been smoothed by

294 hydrodynamic processes other than creep but that the model is unable to explicitly simulate.

295 The channel dynamics is not explicitly simulated, and the channel elevation is kept equal to the lower

296 limit for vegetation growth. This elevation acts as a boundary condition for the bed elevation gradients 
and thus affects the sediment creep flux near the banks. Noticeably, creep from the marsh platform into the channels moves material out of the marsh domain and thus acts as a sink. Creep can also redistribute sediment within the marsh domain; this does not count as either a sink or source because it conserves sediment.

301 Finally, the term $P$ includes the platform elevation loss through pond processes. When a connected cell 302 becomes a pond cell by either pond formation or pond expansion, it loses the elevation $Y=\min \left(Y_{\max }\right.$, $\left.303 \max \left(0, z-z_{\min }\right)\right)$, where $Y_{\max }$ is the maximum scour thickness, calibrated with field data, and $z_{\min }$ is the 304 lower elevation limit below which pond scour does not occur. $Y$ is the thickness of the material that is 305 instantaneously removed from the system, such that the elevation $z$ is lowered by the amount $Y$.

306 The term $P$ also includes pond deepening, which simulates organic matter decomposition via sulfate 307 reduction in the bed of the pond. Pond deepening is set equal to a constant rate $\left(P_{\text {deepening }}\right)$ if $z>z_{\min }$ and to 308 zero if $z<z_{\min }$. Even though we introduced active pond deepening to simulate the loss of elevation caused 309 by organic matter decomposition, this term could be more generally considered as the net effect of all the 310 processes that change pond elevation. For example, if we assume that some sediment settles in the pond 311 during high tide, the term $P_{\text {deepening }}$ should be interpreted as the net deepening, including the actual pond 312 deepening by organic matter decomposition minus the elevation gain caused by sediment deposition. If 313 sediment deposition was larger than organic matter decomposition, $P_{\text {deepening }}$ could be negative, and the 314 pond might gain elevation through time. Given that this parameter is calibrated by comparing measured 315 and modeled pond depths, not by directly measuring the deepening or accretion, we are unable to isolate 316 these two components.

317 To summarize, the pond depth, relative to the surrounding marsh platform, is controlled by three 318 mechanisms: 1) the initial scour, which takes place by either pond formation or expansion, 2) the active 319 pond deepening, and 3) the relative deepening caused by the surrounding marsh gaining elevation through 320 organic and inorganic accretion.

\subsection{Coupling between pond dynamics and elevation dynamics}


322 As outlined above, the bed elevation is affected by pond processes of formation, expansion, and

323 deepening through the term $P$ (Eq. 1). While the cellular automata model formulated in Section 2.2 is

324 independent of bed elevation, the elevation dynamics is introduced by allowing ponds to form and expand

325 only in vegetated marsh cells. This rule keeps ponds from forming and expanding into a mudflat, which is

326 defined as a connected cell with an elevation lower than $z_{\min }$. This model implementation is a result of

327 only allowing the processes associated with isolated pond formation and expansion to occur in highly

328 organic soil that can be oxidized and compressed.

329 If the pond elevation at the time of drainage is higher than $z_{\min }$, the pond revegetates just after it is

330 drained. In other words, the cell instantaneously switches from a pond to a vegetated marsh status. In this

331 scenario, every cell that is not a pond is a vegetated marsh that can be transformed back to a pond through

332 either pond formation or pond expansion. In this case, the pond dynamics without elevation is equivalent

333 to the pond dynamics with elevation, so the cellular automata can be run independently of the elevation.

334 On the other hand, if the connected ponds do not revegetate immediately, they become mudflat cells in

335 which ponds are not allowed to form (because $z<z_{\min }$ ). These areas affect the dynamics of pond formation

336 and expansion, and thus the cellular automata model needs to be run together with the elevation model.

337 A special consideration should be given to cells whose elevation drops below the vegetation limit $z_{\min }$.

338 These cells can be either drowned ponds or mudflats (Fig. 2). Neither has organic accretion by vegetation

339 (Eq. 3), but only the mudflat cells receive inorganic sediment and are allowed to creep under the model

340 specifications. If a drowned pond is surrounded by mudflats, the pond cannot expand. As a result,

341 drowned ponds will never intercept a channel and will never drain in the model domain. In reality,

342 drowned ponds should connect to the channel network through channels that quickly form in the

343 mudflats, but these are not explicitly simulated in the model. Connecting these drowned ponds to creeks

344 will not immediately allow for pond revegetation since the pond is still below the vegetation limit, but it

345 will allow for inorganic accretion and creep, which will both increase the bed elevation and potentially

346 allow for revegetation. In the model we account for this dynamic by introducing the rule that any drowned 
pond that touches a mudflat becomes a mudflat itself, and receives inorganic sediment. Then, the evolution of the mudflat would follow the elevation dynamics as previously described.

To summarize, the pond dynamics can be affected by the presence of mudflat cells, since ponds cannot form or expand into these cells. The formation of mudflats is controlled by active pond deepening $\left(P_{\text {deepening }}\right)$ and by RSLR; the recovery of mudflats is controlled by mud accumulation and by RSLR (Fig.

2). If the amount of mudflats at any time is negligible (a few percent of the total marsh area), then the 353 elevation dynamics would in practice not affect the pond dynamics.

\section{4. Results}

\section{$355 \quad 4.1$ Field measurements}

356 The pond expansion rate, calculated using remote sensing, was equal to $\sim 1.5 \mathrm{~cm} / \mathrm{yr}$, with a weak

357 dependence on the pond size (Fig. 3). This is calculated for ponds that did not merge between 1973 and

3582014 and thus only includes ponds smaller than about $20 \mathrm{~m}$. We were not able to measure expansion for

359 larger ponds. Detailed transects across thirteen ponds indicate that ponds are 0.3-1.2 m deep and that their 360 depth increases with diameter. The survey of 200 marsh-pond boundaries revealed that the depth of the 361 pond immediately adjacent to the bank was $0.46 \pm 0.21 \mathrm{~m}$. As such, the depth of the pond close to the edge

362 is relatively uniform, whereas the depth in the middle of the pond has a greater variability. Field

363 measurements at Barnstable marsh show an accretion of $4.6 \pm 2.5 \mathrm{~mm} / \mathrm{yr}$ near the channel and 5.1 \pm 3.3

$364 \mathrm{~mm} / \mathrm{yr}$ in the marsh interior over the past 100 years (Table 1). Total suspended sediment concentrations

365 were $29.3 \pm 3.6 \mathrm{mg} / \mathrm{l}$ for Barnstable and $5.0 \pm 2.8 \mathrm{mg} / \mathrm{l}$ for Sage Lot pond.

\subsection{Pond dynamics not coupled to elevation}

367 The model simulations were run in a portion of the Barnstable marsh about $1.2 \times 1.2 \mathrm{~km}$ (Fig. 1C). Using 368 the 2014 Lidar topography, the channel network was defined as the area with an elevation lower than the 369 limit for vegetation growth, which was assumed to be equal to MSL. Areas that were identified as ponds 370 (Section 2.1) were excluded from the channel network. 
371 The pond model is first run without including the requirement that ponds can only form and expand

372 where the marsh elevation is greater than $z_{\min }$. In this case, the pond dynamics does not depend on bed

373 elevation. This simplification is equivalent to the fully coupled model if the pond elevation never drops

374 below $z_{\min }$, and it is nearly equivalent to the fully coupled model if the amount of mudflats is negligible,

375 which is the case if mudflats recover quickly. The advantage of running the model without the elevation

376 dynamics is to emphasize a key feature of pond dynamics, that is, the spatial distribution of ponds does

377 not depend on RSLR and sediment supply. As such, the parameters for pond evolution $\left(k_{\text {seed }}\right.$ and $\left.k_{\text {exp }}\right)$ can

378 be calibrated against observations without being affected by the uncertainties associated with RSLR (and

379 its variability during the last century) and sediment supply (which is estimated using a limited number of

380 samples).

381 Starting with a marsh without ponds, we run the model for 1000 years to reach a steady state, defined as

382 the period in which the time-averaged statistical distribution of ponds does not change. We found that

383 pond dynamics does not depend on the size of the ponds formed via the seeding mechanism, rather the

384 same steady state pond distribution is obtained if the ponds formed by the seeding mechanism are

385 composed of a single or several cells (and thus the initial ponds is larger). This occurs because the amount

386 of pond area created by seeding, where ponds are introduced into the model, is small compared to the area

387 gained by pond expansion. As such, the main effect of pond formation is not to directly increase the pond

388 area, but rather to create "seeds" that allow for pond expansion. This also confirms that pond formation

389 should have units of \#ponds $\cdot \mathrm{m}^{-2} \mathrm{yr}^{-1}$ and not $\mathrm{of}^{2} \mathrm{~m}^{-2} \mathrm{yr}^{-1}$.

390 We found that the steady state pond size distribution only depends on the ratio between pond formation

391 and expansion rates. This is confirmed by noticing that the ratio between the two rates has units of

392 \#ponds $/ \mathrm{m}^{3}$ and is independent of time. The actual values of the rates only affect the time needed to reach

393 the steady state distribution. The ratio between pond formation and expansion rate that best fits the pond

394 size distribution (Fig. 4) is 0.027 \#ponds $/ \mathrm{m}^{3}$. If the ratio decreases, the number of small ponds decreases

395 while allowing for only a few large ponds (Fig. 4). Intuitively, in this scenario each pond has more time to 
expand before eventually being drained. Using the measured pond expansion rate $(1.5 \mathrm{~cm} / \mathrm{yr})$, the pond

397 formation rate is estimated to be $4 \cdot 10^{-4}$ ponds $\cdot \mathrm{m}^{-2} \mathrm{yr}^{-1}$. We could not directly measure this rate because of 398 the difficulty of detecting small ponds.

\subsection{Elevation dynamics}

Simulations that include the elevation dynamics (Section 2.3) are run for 1000 years, in which the first 900 years have $R$ of $1 \mathrm{~mm} / \mathrm{yr}$ and the last 100 years have $R$ of $2.9 \mathrm{~mm} / \mathrm{yr}$, thus representing the RSLR acceleration in the $19^{\text {th }}$ century (NOAA Woods Hole Station 8447930). Thus, year 900 of the simulation roughly corresponds to year 1914, whereas year 1000 roughly corresponds to year 2014 (i.e., present time). The model at year 0 is initialized with an elevation equal to the $90^{\text {th }}$ percentile of the vegetation range, i.e., $0.9(r / 2)=1.62 \mathrm{~m}$. Despite this initialization of marsh elevation being arbitrary, it does not affect the results after about 500 years. Put differently, any initial marsh elevation would lead to the (statistically) same results during the last few hundred years of the simulation. As such, this approach recreates a synthetic marsh representative for the beginning of the $20^{\text {th }}$ century that is 1 ) at steady state according to the processes included in the model, 2) independent of any arbitrary initial marsh elevation, 3) independent of any topography measured at present time. Specifically, the measured Lidar is not used to initialize the marsh elevation nor the pond distribution. Only the geospatial distribution of channels (which could be reconstructed from aerial images without elevation) is needed to initialize the model.

First, we consider the elevation dynamics without the presence of ponds (Fig. 5). We analyze this scenario by considering the spatially averaged vertical fluxes over the marsh domain (Fig. 6). As expected, the net vertical accretion is equal to the RSLR rate. When RSLR rate increases to $2.9 \mathrm{~mm} / \mathrm{yr}$, the net vertical accretion lags behind, but it nearly matches the RSLR rate after about 100 years (i.e., at present times). The gross vertical accretion at present times is $5.1 \mathrm{~mm} / \mathrm{yr}$. This value represents the spatially averaged accretion rate; in reality the accretion is much higher in the marsh adjacent $(<10 \mathrm{~m})$ to channels, where it can be up to $20 \mathrm{~mm} / \mathrm{yr}$ (Figs. 5, 7C). This additional accretion is balanced by bank creep, which transports sediment out of the marsh domain. When spatially averaged over the entire marsh, 
421 this creep flux creates an equivalent deficit of $2.2 \mathrm{~mm} / \mathrm{yr}$, which allows the net vertical accretion to

422 balance the RSLR rate (Fig. 6).

423 Next, we run the model including the mechanisms of pond formation, expansion, and deepening. The 424 maximum initial pond depth $Y_{\max }$ (which is both the maximum initial scour of new ponds, as well as the 425 maximum initial scour when the pond edge expands) is set equal to the measured height of the pond edge, 426 which was measured for Barnstable marsh to be $0.46 \mathrm{~m}$. The consequences of this choice in the model are 427 that 1) small ponds would have a nearly uniform depth across the pond, and that depth would be about $4280.46 \mathrm{~m}, 2$ ) larger ponds would have a depth greater than $0.46 \mathrm{~m}$ in their center, which is older and thus 429 may have deepened over time due to organic matter decomposition as well as accretion of the adjacent 430 marsh platform, whereas their edges, which formed recently, would have a depth of $\sim 0.46 \mathrm{~m}$. The active 431 pond deepening $P_{\text {deepening }}$ was instead calibrated to match the observed depth in the middle of the ponds 432 (Fig. 8). As expected, the pond depth is much greater in the middle than at the edge, and the depth in the 433 middle of the pond increases with the pond diameter.

434 Ponds do not affect the marsh dynamics in the buffer zone close to the channel network, where ponds are 435 drained instantaneously. This is equivalent to assuming that they do not form at all and cannot expand. As 436 such, the model that includes pond dynamics has a similar pattern of bank creep and excess accretion on 437 the marsh adjacent to the channel as the model without pond dynamics (Fig. 6). On the other hand, ponds 438 drastically change the dynamics of the marsh interior. Ponding creates a heterogeneous landscape, with 439 low elevation areas surrounded by high marsh areas. This elevation pattern is mirrored by a spatially 440 heterogeneous vertical accretion, where the net vertical accretion in ponds is zero (if not negative, 441 because of active pond deepening), whereas recently connected ponds experience enhanced vertical 442 accretion. Compared to the case without ponds, the average marsh elevation is also lower.

443 Because pond reconnection is a stochastic process, the vertical accretion rate is not constant in time. In 444 particular, there are periods when large ponds are drained and the vertical accretion suddenly increases 445 (Fig. 6). Over a sufficient time period (e.g. 50 years), however, the net vertical accretion rate is equal to $R$. 


\subsection{Exploring the effects of RSLR rate, sediment supply, and tidal range}

447 To generalize our results, we perform a series of explorative simulations with different sediment supplies

$448\left(C_{o}\right)$, RSLR rates $(R)$, and tidal ranges $(r)$. In order to consistently initialize the simulations, we start with 449 a uniform elevation equal to $0.9(r / 2)$ with no ponds, and then run the model with $R$ equal to $1 \mathrm{~mm} / \mathrm{yr}$ for 450500 years, which is enough to establish a steady state pond distribution (Fig. 6). As already pointed out, 451 the choice of the initial elevation does not affect the results after about 500 years. After 500 years, we 452 changed a single parameter (either $R$ or $C_{o}$ ) while keeping all the other parameters fixed, and run the 453 simulations for an additional 1000 years (Fig. 9). We focused on scenarios in which the vegetated marsh 454 kept pace with RSLR and thus all marsh loss is due to pond expansion.

455 First, we consider the effects on increasing $R$ or decreasing $C_{o}$ in a mesotidal marsh such as Barnstable marsh. For the relatively high sediment supply of Barnstable marsh $\left(C_{o}=30 \mathrm{mg} / \mathrm{l}\right)$, the RSLR rate does not

457 affect the dynamics of ponds, which always occupies $\sim 10 \%$ of the marsh. For the case with a lower $C_{o}=10$ $458 \mathrm{mg} / \mathrm{l}$, lower $R$ gives nearly identical results as for the case with a higher $C_{o}$, with pond area remaining at $459 \sim 10 \%$ of the total marsh area, whereas high $R$ starts to affect pond area (Fig. 9A). For example, for $C_{o}=10$ $\mathrm{mg} / \mathrm{l}$ and $R=8 \mathrm{~mm} / \mathrm{yr}$, the total unvegetated area (ponds plus mudflats) increases to about $25 \%$ within 500

461 years (Fig. 9A). Noticeably, under these conditions, the unvegetated area stabilizes and does not increase 462 indefinitely even after 1000 years.

463 Next, we consider the case of a marsh with a smaller tidal range. We use as a reference Sage Lot Pond 464 marsh, which has a spring tidal range of $0.7 \mathrm{~m}$ (Gonneea et al, 2019). Field measurements indicate that 465 this marsh has a small sediment supply equal to $5 \mathrm{mg} / \mathrm{l}$. For simplicity, we consider the same channel 466 geometry as of Barnstable marsh but with a smaller tidal range. Accordingly, we modify the vegetation 467 limit, the initial marsh elevation, the maximum initial pond elevation, and the spring-neap variability 468 (Table 2). For the microtidal case, we found that for low $R$ the unvegetated area is still $\sim 10 \%$, but for 469 higher rates the unvegetated area increases quickly, and can be up to $100 \%$, indicating loss of the entire 
$471 R \sim 3 \mathrm{~mm} / \mathrm{yr}$ (Fig. 9B).

472 We also compared the model predictions with the measured accretion rates in Barnstable and Sage Lot

473 Pond marsh. We separated the spatially averaged accretion predicted by the model between the marsh

474 adjacent to channels (less than $10 \mathrm{~m}$ from the nearest channel, which roughly coincides with the low

475 marsh, and is about $29 \%$ of the total marsh area) and the marsh interior (more than $10 \mathrm{~m}$ from the nearest

476 channel, where bank creep is virtually zero, and is about $71 \%$ of the total marsh area). For a marsh with

477 low tidal amplitude and sediment supply such as Sage Lot Pond, the model predicts that when RSLR rate

478 was $1 \mathrm{~mm} / \mathrm{yr}$, the gross vertical accretion rates was $\sim 2.6 \mathrm{~mm} / \mathrm{yr}$ in the marsh adjacent to channels and

$479 \sim 1.4 \mathrm{~mm} / \mathrm{yr}$ for the marsh interior (Fig. 7B). After the acceleration in RSLR to $2.9 \mathrm{~mm} / \mathrm{yr}$ the model

480 predicts that the gross vertical accretion increases to $\sim 4.1 \mathrm{~mm} / \mathrm{yr}$ in the marsh adjacent to the channels and

481 to $\sim 3 \mathrm{~mm} / \mathrm{yr}$ in the marsh interior (Fig. 7B). For comparison, the field measurements of accretion over a

482100 year period, which includes the period during modern RSLR acceleration, indicate an accretion rate

483 of $3.7 \pm 2.0 \mathrm{~mm} / \mathrm{yr}$ close to the channels and $1.4 \pm 0.3 \mathrm{~mm} / \mathrm{yr}$ in the interior (Table 1). For the Barnstable

484 marsh, with a higher tidal range and sediment supply, the model predicts gross vertical accretion rates of

$485 \sim 9.5 \mathrm{~mm} / \mathrm{yr}$ near channels and $\sim 2.8 \mathrm{~mm} /$ year in the marsh interior when RSLR rate is $1 \mathrm{~mm} / \mathrm{yr}$, and $\sim 11.5$

$486 \mathrm{~mm} / \mathrm{yr}$ near channels and $\sim 4.0 \mathrm{~mm} / \mathrm{year}$ in the marsh interior when RSLR rate is $2.9 \mathrm{~mm} / \mathrm{yr}$ (Fig. 7A). For

487 comparison, field measurements at Barnstable marsh show an accretion of $4.6 \pm 2.5 \mathrm{~mm} / \mathrm{yr}$ near the

488 channel and $5.1 \pm 3.3 \mathrm{~mm} / \mathrm{yr}$ in the marsh interior over the past 100 years.

489 As an indicator of the overall marsh status, we calculated the spatially-averaged primary productivity

490 normalized by the maximum productivity (Fig. 9). The productivity of the vegetated marsh depends on

491 the bed elevation following the function $B$ (section 3.3), whereas the productivity in the ponds is equal to

492 zero. As the RSLR rate increases, the marsh elevation decreases and thus the productivity increases. As

493 the unvegetated pond area starts to increases, however, the overall marsh productivity starts to decrease.

494 This is particularly evident for the Sage Lot Pond marsh for a RSLR rate greater than $4 \mathrm{~mm} / \mathrm{yr}$ (Fig. 9B). 
Finally, we expanded these simulations by systematically considering different tidal ranges $(0.7,1.6,3.6$ m), RSLR rates (1 to $8 \mathrm{~mm} / \mathrm{yr}$ ), and sediment supply concentrations (5 to $30 \mathrm{mg} / \mathrm{l}$ ) (Fig. 10). We found that, for small tidal ranges, the rate of marsh loss by pond expansion is highly sensitive to the RSLR rate. When the RSLR rate increases to $3 \mathrm{~mm} / \mathrm{yr}$, marsh loss occurs but is relatively slow, and the amount of unvegetated area (which includes both ponds and mudflats) increases from $10 \%$ to $15 \%$ of the total marsh area during the first 100 years (Fig. 9). A further increase in the RSLR rate (5 mm/yr) drastically increases the rate of marsh loss, with the amount of unvegetated area increasing from $10 \%$ to $40 \%$ of the 502 total marsh area during the first 100 years.

\section{Discussion}

\subsection{The pervasive effect of ponds in salt marshes}

505 Ponds in Barnstable marsh expand at a very slow rate $(1.5 \mathrm{~cm} / \mathrm{yr})$ compared to exposed marsh creekbank 506 edges that retreat by wave-induced erosion (0.5-10 m/yr) (Elsey-Quirk et al., 2019; Hopkinson et al., 2018; Leonardi et al., 2016; Marani et al., 2011). Yet, ponds are numerous and collectively have a long perimeter, and thus are able to affect nearly the entire marsh surface on millennial time scales. Considering an average unchanneled length of $50 \mathrm{~m}$ (Marani et al., 2003), a pond formed in the middle of the marsh would take 2000 years to reach an area influenced by channel network and drain. Since some ponds form closer to the channel network initially, 2000 years is likely an upper estimate of the time needed to reconnect ponds to the channel network and drain. In addition, ponds that merge together will drastically reduce the time needed for a pond to reconnect to the channel network.

514 Given that the Barnstable marsh is $\sim 4000$ years old (Redfield, 1965), we expect that any point on the 515 marsh was at least once a pond. Indeed, stratigraphic evidence of ponds were found in nearly all cores 516 taken in a New England salt marsh (ME, USA) (Wilson et al., 2009). However, many historical records 517 within salt marshes only extend $\sim 100$ years, due to age model constraints of the commonly used lead-210 518 methods, and thus may miss some of these millennial scale dynamics. In any case, the assumption of 519 steady state marsh accretion often used while interpreting the sedimentary record (Morris et al., 2016) 
should be evaluated, since even if RLSR rate and sediment supply are constant, a specific site within the

521 marsh may not be at steady state at any given time due to pond dynamics.

522 Another consequence of pond dynamics is that recently connected ponds (as identified in Fig. 1E) are a

523 common feature and should be interpreted as part of the basic marsh dynamics as opposed to an indicator

524 of changes in boundary conditions. Thus, ponds do not necessarily indicate an acceleration in RSLR or

525 other anthropogenic modifications, but are rather a natural occurrence within many salt marshes. Ponds

526 also create diverse habitats and ecological niches for wildlife (Brush et al., 1986), and thus should not

527 necessarily be considered a negative feature within salt marshes.

\section{$528 \quad 5.2$ Vertical accretion in the pond recovery regime}

529 When the marsh is in the pond recovery regime, pond dynamics in the marsh interior increased the

530 spatially-averaged gross vertical accretion by $0.5-2 \mathrm{~mm} / \mathrm{yr}$ (Fig. 7), a result that was previously predicted

531 (Kirwan et al., 2008). This excess accretion is larger for larger tidal ranges, because marshes with a larger

532 tidal range have a thicker soil profile that can be removed by the ponding processes. Ponding also results

533 in highly heterogeneous accretion across the marsh platform (Fig. 5), and thus the excess accretion rate

534 during pond recovery could locally be much higher than $2 \mathrm{~mm} / \mathrm{yr}$. For example, the model predicts that

535 recovering ponds might have accretion rates up to $20 \mathrm{~mm} / \mathrm{yr}$ (Fig. 5). Indeed, Wilson et al., (2014)

536 reported vertical accretion rates of $8 \mathrm{~mm} / \mathrm{yr}$ in recently recovered ponds in a New England salt marsh,

537 despite the fact that the sediment supply in that marsh was extremely low $(\sim 5 \mathrm{mg} / \mathrm{l})$. The model predicts

538 that the excess accretion rate persists from when a pond revegetates until it reaches the equilibrium

539 elevation with the marsh surface. In other words, ponds that were drained centuries ago might not have

540 fully equilibrated and thus might still accrete slightly faster than the RSLR rate. These predictions are

541 consistent with the $5.1 \mathrm{~mm} / \mathrm{yr}$ vertical accretion measured in the marsh interior of Barnstable marsh

542 during a period when relative sea-level rise rate was $2.9 \mathrm{~mm} / \mathrm{y}$ (NOAA Woods Hole Station 8447930)

543 (Table 1). 
544 Our model also predicts channel bank creep causes an equivalent elevation drop of $\sim 2 \mathrm{~mm} / \mathrm{yr}$ when 545 averaged over the whole marsh platform (Fig. 6,7). This loss is balanced by an excess vertical accretion 546 (Mariotti et al., 2016), which can be observed by the gross vertical accretion rate being much larger than 547 the RSLR rate. Contrary to ponding, this bank creep is localized to the low marsh immediately adjacent to 548 channels, where the excess vertical accretion can be an order of magnitude higher than RSLR rate (i.e., up 549 to $20 \mathrm{~mm} / \mathrm{yr}$, Fig. 5). This prediction is consistent with the larger vertical accretion rates measured on the 550 marsh adjacent to channels than on the marsh interior at Sage Lot Pond marsh (Table 1). For Barnstable 551 marsh, the model predicts that the vertical accretion on the marsh adjacent to channels is $\sim 11 \mathrm{~mm} / \mathrm{yr}$ (Fig. 552 7A), which is much larger than the measured $4.6 \pm 2.5 \mathrm{~mm} / \mathrm{yr}$ (Table 1). One possible explanation is that 553 the channel-adjacent area in the model integrates portions of the marsh that are extremely low (e.g., the 554 vegetated bank located a few meters from the channel). These low areas have a disproportionally high 555 excess accretion (Fig. 5 and Fig. 7C,D) and strongly influence the average value over the area here 556 defined as channel-adjacent ( $<10 \mathrm{~m}$ from the channel network). Field measurements in the channel557 adjacent area, in contrast, are generally taken a few meters inland from the edge of the marsh, with a 558 higher elevation than the slumping blocks and where the excess accretion is much lower. Indeed, the 559 cores in Barnstable collected $\sim 2 \mathrm{~m}$ from the marsh edge are actually $\sim 5 \mathrm{~m}$ from the lowest vegetated point 560 (Fig. 1H). Noticeably, the model predicts a minimum in vertical accretion, equal to about $3 \mathrm{~mm} / \mathrm{yr}$, 561 located between 5 and $20 \mathrm{~m}$ from the channel (Fig. 7C). This is the region where neither bank creep nor 562 ponding are present, and thus the gross accretion rate matches RSLR rate.

563 The model also recreates the lagged vertical accretion that follows the acceleration in RSLR rate, a 564 disequilibrium effect has been previously identified with simplified marsh models (Kirwan and 565 Temmerman, 2009; Kirwan and Murray, 2008). This lag should be present in every salt marsh that 566 experienced accelerated RSLR, regardless of pond occurrence or the influence of bank creep.

567 To summarize, the model is able to combine three previously identified mechanisms by which vertical 568 accretion rates deviate from the RSLR rate, emphasizing that a direct comparison between vertical 
accretion and RSLR rate can be misleading at best, and overly optimistic for projecting marsh elevation

570 trajectories.

\section{$571 \quad 5.3$ Vertical accretion in the pond runaway regime}

572 The simple lumped model (Mariotti, 2016) identified the minimum unvegetated accretion,

$573 D_{c r}=C \cdot r /\left(2 T \cdot \rho_{m}\right)$, as the threshold between pond recovery and pond runaway regimes. Because $C$ is not

574 spatially uniform, $D_{c r}$ varies among the domain. $D_{c r}$ is lowest in the marsh interior, where

$575 \quad D_{c r}=\alpha \cdot C_{o} \cdot r /\left(2 T \cdot \rho_{m}\right)$.

576 For $R<D_{c r}$, the lumped pond model predicts that every pond recovers. Indeed, the spatially explicit model

577 predicts that, for any RSLR rate lower than $D_{c r}$, ponds always occupy $\sim 10 \%$ of the marsh area (Figs.

578 9,10). This prediction agrees with the finding that stable salt marshes are associated with an unvegetated-

579 vegetated ratio of $\sim 0.1$ (Wasson et al., 2019) (a pond area of $10 \%$ corresponds to an unvegetated-

580 vegetated ratio of 0.11 ). As for the lumped model, the spatially explicit model predicts an increase in the 581 total unvegetated area as $R>D_{c r}$. The spatially explicit model provides more information than the lumped

582 model, and specifically predicts that the rate at which marsh loss by pond expansion takes place strongly

583 increases as $R$ further exceeds $D_{c r}$. Put differently, when $R$ is just slightly above $D_{c r}$, the rate of marsh loss

584 by pond expansion is extremely low, and the marsh could last thousands of years. On the other hand, once

585 the threshold for pond runaway is exceeded, even small increases in $R$ could have catastrophic

586 consequences for marsh loss.

587 Using $D_{c r}$ as the threshold for the pond runaway regime is further complicated by the presence of creep,

588 which can take place at the edge of mudflats (i.e., connected ponds). Creep transfers sediment from high

589 to low elevations, and thus tends to increase vertical accretion in the mudflats and to lower vertical

590 accretion on the vegetated platform. For example, a very small mudflat might recover even if $R$ is slightly

591 larger than $D_{c r}$ (which explains why the Sage Lot Pond marsh does not enter the pond runaway regime for

$592 R=1 \mathrm{~mm} / \mathrm{yr}$ even if $D_{c r}=0.6 \mathrm{~mm} / \mathrm{yr}$ ). Lateral transport of sediment not associated with creep, including

593 sediment transport by waves or sheet flow over the marsh, might slightly alter the predictions purely 
based on vertical accretion rates. Nonetheless, the parameter $D_{c r}$ captures the transition to the pond runaway regime within an uncertainty of about $1 \mathrm{~mm} / \mathrm{yr}$ (Fig. 10).

\subsection{Pond formation}

597 A crucial parameter in the model is the rate of pond formation. If ponds do not form, neither the pond

598 recovery nor the pond runaway regime occurs. In this case, the marsh is either fully vegetated or

599 disappears by drowning, and thus the marsh landscape is dramatically different than what simulated in our

600 model (Fig. 5). As such, it is noteworthy to emphasize that ponds are not always present in salt marshes.

601 Ponds have been identified in the Mid-Atlantic and New England Coast of the USA (Adamowicz and

602 Roman, 2005; Mariotti, 2016; Schepers et al., 2017) as well as in the northern Gulf of Mexico (Mariotti,

603 2016; Nyman et al., 1994). Yet, marshes in the South-Atlantic Coast of the USA, including sites with

604 relatively little human modifications such as in Virginia and Georgia, seem to have few ponds if any at

605 all. For marshes in which ponds are not common, it is possible that either ponds do not form at all or that

606 the pond formation rate (the parameter $k_{\text {seed }}$ ) is extremely low. In this latter case the model would predict

607 that the number of ponds would be highly reduced (Fig. 4) and that their size distribution would be highly

608 skewed towards a few large ponds.

609 In this study, we assumed that ponds form without explicitly simulating the mechanisms that lead to pond

610 formation in the first place. In particular, we did not investigate whether the rate of pond formation

611 changes as a function of environmental drivers. We can only speculate that pond formation might be

612 related to disturbances related to climate via ice rafting and scour, excessive wrack accumulation,

613 grazing/bioturbation such as by Sesarma reticulatum crab or burrowing species such as fiddler crabs (Uca

614 sp.), and to biogeochemical and hydrological processes associated with microtopography.

615 We further emphasize that pond formation per se is not directly driving permanent marsh loss, but it 616 could lead to marsh loss in the pond runaway regime. In the pond runaway regime, an increase in the 617 pond formation rate would directly increase the rate at which the marsh is lost, mainly by increasing the 618 "seeds" from which ponds can expand. Pond formation is thus an example of a relatively secondary 
mechanism that, through spatial interactions (Larsen, 2019), could lead to rapid marsh loss. Thus, we

620 argue that future research should develop a mechanistic understanding of pond formation and determine

621 whether environmental changes such climate or burrowing and grazing pressure, might increase the rate

622 of pond formation.

\section{$623 \quad 5.5$ Marsh management}

624 All simulations were performed for scenarios in which the vegetated marsh keeps pace with RSLR. As 625 such, if pond dynamics were not included, the marsh would have been preserved indefinitely and there 626 would have not been any unvegetated area occupied by either ponds or mudflats. Thus, including pond

627 dynamics in marshes where ponds are known to form is an essential step to simulate marsh evolution.

628 Including pond dynamics in marsh models is also essential for predicting ecosystem productivity. Marsh

629 grasses remove $\mathrm{CO}_{2}$ from the atmosphere and bury it in soils, support coastal food webs, and filter

630 inorganic nutrients washed from the landscape, among other ecosystem services. As such, changes in

631 productivity have consequences for ecological and biogeochemical processes within marshes and adjacent 632 ecosystems. In both the mesotidal (Barnstable) and microtidal (Sage Lot Pond) simulations, normalized 633 primary productivity increases monotonically with the RSLR rate (Fig. 9). The expansion of the 634 unvegetated area for very high RSLR rates, however, starts to decrease productivity. For the microtidal 635 case, a decrease in productivity associated with pond expansion could be observed even at the decadal 636 time scale (Fig. 9B), and thus could be relevant for coastal management.

637 As previously identified (Mariotti, 2016), neither the presence of ponds nor the expansion of ponds is a 638 sign of permanent marsh loss. On the other hand, the absence of pond recovery is a potential indicator of 639 a regime shift. Monitoring pond recovery, such as by measuring their accretion rates once reconnected to 640 the channel network, should thus become a routine marsh assessment, alongside measurements of vertical 641 accretion in the vegetated marsh. 
642 One management question is whether to promote or prevent pond recovery. One example includes

643 selectively digging ditches to reconnect ponds, a strategy referred to as "quality ditching" or Open Water

644 Marsh Management (Wolfe, 1996). Our model suggests that the appropriate management (in terms of

645 morphological evolution of the salt marsh) depends on whether the marsh is in the pond recovery or pond

646 runaway regime. In the former case, favoring pond drainage should accelerate vertical accretion, in the

647 latter it would accelerate marsh loss.

648 As previously shown in a model that only considers one pond (Mariotti, 2016), determining whether a

649 marsh is in the pond runaway or pond recovery regimes requires an estimate of the minimum inorganic

650 deposition in the marsh interior $\left(D_{c r}\right)$, and specifically to estimate the suspended sediment concentration.

651 Because this parameter is difficult to determine without long-term monitoring (Ganju et al., 2017), we

652 suggest that analyzing the trajectory of recently connected ponds is important to determine whether ponds

653 are recovering or expanding indefinitely.

\section{$654 \quad 5.6$ Model limitations and future directions}

655 The model assumes that any connected area above $z_{\min }$ revegetates instantaneously. Therefore, a mudflat

656 is only present if $z<z_{\min }$. In reality it could take several years for a connected pond to revegetate even if

$657 z>z_{\min }$. For example, the recently connected ponds in Barnstable have not fully revegetated even if their

658 elevation is $\sim 1 \mathrm{~m}$ above MSL (i.e., $\mathrm{z}>z_{\min }$ ). Even though this delay could be included in the dynamics, we

659 argue that it is not crucial, because revegetation likely will occur within shorter times scales (decades)

660 than the time scale considered in this study. More importantly, large vertical accretion rates by mud

661 deposition could take place even though recently connected ponds are not fully revegetated.

662 Channels are assumed to be fixed. When analyzing historical imagery ( 50 years), channels in Barnstable

663 marsh are relatively stable, even though they could have migrated over longer time scales. Migrating

664 channels would likely increase the rate at which ponds are intercepted and thus drained. Channel

665 migration could be parameterized as a larger value for the reference drainage distance $L$, allowing ponds

666 within the model to drain even if located at a large distance from channels. Indeed, this could be a 
dominant mechanism for pond drainage at sites where channel migration is relatively fast (Finotello et al.,

668 2018). Channel migration would likely result in similar marsh evolution dynamics and pond recovery,

669 with marsh loss at the eroding bank but, at the same time, induce accretion that is faster than the RSR

670 rate at the accreting bank.

671 The model does not conserve sediment in the channel domain: the sediment transported from the bank to

672 the channel through the creep mechanism does not accumulate in the channel, and the sediment

673 transported from the channel to the marsh, which is responsible for the term $D_{m}$, does not cause a

674 sediment deficit in the channel network. That is, we assume that there is an infinite supply of new

675 sediment from the channels. In reality, a portion of the bank material that creeps into the channel would

676 be resuspended and re-transported to the marsh platform, thus allowing for sediment recycling. This

677 component cannot be reproduced in the model, since an explicit representation of the channel dynamics

678 would be needed.

679 Finally, the model does not include the dynamics of hydrological alterations such as ditching, which is a 680 common feature in New England salt marshes. Ditching could impact the marsh elevation dynamics in at least two ways. On one hand, ditches could cause a nearly instantaneous marsh-wide pond drainage, which could temporarily increase the spatially averaged vertical accretion rate. On the other hand, ditches could lower the water table and cause a combination of carbon oxidation and compaction, which in turn could lower the marsh elevation. Such effects could be included in the model by 1) allowing ponds close to the ditches to be drained similarly to the ponds drained by the natural channel network, and 2) adding an additional term in Eq. 1 to simulate a localized bed lowering close to the ditches.

\section{6. Conclusions}

688 The proposed model simulates the spatially explicit dynamics of marsh ponds, and thus allows simulation 689 of the aggregated effect that ponds have on the evolution of the marsh platform. The Barnstable marsh is 690 predicted to be in a pond recovery regime: pond expansion does not cause net marsh loss because they 691 recover the marsh elevation once drained. Even in the pond recovery regime, however, ponds drastically 
692 affect the marsh elevation and vertical accretion. In particular, pond dynamics explain why marsh vertical

693 accretion, even away from channels, could be several times larger than the rate of RSLR, and also why

694 the accretion rate is highly variable in space.

695 The model predicts that future increases in RSLR rate at Barnstable marsh would not cause the marsh to

696 transition to the full pond runaway regime. Yet, with a large RSLR rate and a reduced sediment supply,

697 ponds in the marsh interior might become permanent mudflats and thus increase the unvegetated area to

$698 \sim 20 \%$ of the total marsh. Monitoring of pond recovery, such as by measuring their accretion rates once

699 reconnected to the channel network, could be used as a landscape-level indicator of regime shifts.

700 Marshes with a smaller tidal range and sediment supply, such as Sage Lot Pond marsh, are more prone to 701 enter the pond runaway regime. For RSLR rates just above the critical threshold (e.g., $3 \mathrm{~mm} / \mathrm{yr}$ ), the rate

702 of marsh loss by pond expansion is still relatively low, and the marsh could take several centuries (if not

703 millennia) before completely disappearing. A further acceleration in RSLR rate (e.g., $5 \mathrm{~mm} / \mathrm{yr}$ ) would

704 drastically increase the rate at which the marsh is lost by pond expansion - which will take place even

705 though the vegetated marsh keeps pace with RSLR.

706 Future research needs include understanding the mechanism of pond formation, evaluating how

707 hydrological alterations such as ditching affects pond dynamics, and quantifying how pond dynamics

708 affect blue carbon accumulation and preservation.

\section{Acknowledgments}

711 We appreciate funding support for this work from Woods Hole Sea Grant (NA14OAR4170104 to ACS

712 and GM) and NOAA NSC (NA14NOS4190145 to ACS, GM, MEG, and MT), USGS Coastal \& Marine

713 Geology Program, the USGS Land Change Science Program's LandCarbon program. We thank the

714 Waquoit Bay National Estuarine Research Reserve and Sandy Neck Beach Park for providing research

715 access. USGS staff including T. Wallace Brooks, Jennifer O'Keefe Suttles, Adrian Mann and Allyson 
Boggess provided field and analytical support. Additional field support was provided by Claire Mayorga, Kelsey Gosselin, Madelyn Francesconi, and Sam MicNichol. Any use of trade, firm or product names is for descriptive purposes only and does not imply endorsement by the U.S. Government.

\section{References}

Adamowicz, S.C., Roman, C.T., 2005. New England salt marsh pools: A quantitative analysis of geomorphic and geographic features. Wetlands 25, 279-288. https://doi.org/10.1672/4

Appleby, P.G., Oldfield, F., 1978. The calculation of lead-210 dates assuming a constant rate of supply of unsupported $210 \mathrm{~Pb}$ to the sediment. CATENA 5, 1-8. https://doi.org/10.1016/S03418162(78)80002-2

Argow, B.A., FitzGerald, D.M., 2006. Winter processes on northern salt marshes: Evaluating the impact of in-situ peat compaction due to ice loading, Wells, ME. Estuar. Coast. Shelf Sci., Salt Marsh Geomorphology: Physical and ecological effects on landform 69, 360-369. https://doi.org/10.1016/j.ecss.2006.05.006

Argow, B.A., Hughes, Z.J., FitzGerald, D.M., 2011. Ice raft formation, sediment load, and theoretical potential for ice-rafted sediment influx on northern coastal wetlands. Cont. Shelf Res. 31, 12941305. https://doi.org/10.1016/j.csr.2011.05.004

Binford, M.W., 1990. Calculation and uncertainty analysis of $210 \mathrm{~Pb}$ dates for PIRLA project lake sediment cores. J. Paleolimnol. 3, 253-267. https://doi.org/10.1007/BF00219461

Brush, T., Lent, R.A., Hruby, T., Harrington, B.A., Marshall, R.M., Montgomery, W.G., 1986. Habitat Use by Salt Marsh Birds and Response to Open Marsh Water Management. Colon. Waterbirds 9, 189-195. https://doi.org/10.2307/1521212

Cavatorta, J.R., Johnston, M., Hopkinson, C., Valentine, V., 2003. Patterns of sedimentation in a salt marsh-dominated estuary. Biol. Bull. 205, 239-241.

Christiansen, T., Wiberg, P.L., Milligan, T.G., 2000. Flow and Sediment Transport on a Tidal Salt Marsh Surface. Estuar. Coast. Shelf Sci. 50, 315-331. https://doi.org/10.1006/ecss.2000.0548

Cutshall, N.H., Larsen, I.L., Olsen, C.R., 1983. Direct analysis of 210Pb in sediment samples: Selfabsorption corrections. Nucl. Instrum. Methods Phys. Res. 206, 309-312. https://doi.org/10.1016/0167-5087(83)91273-5

Elsey-Quirk, T., Mariotti, G., Valentine, K., Raper, K., 2019. Retreating marsh shoreline creates hotspots of high-marsh plant diversity. Sci. Rep. 9, 5795. https://doi.org/10.1038/s41598-019-42119-8

Fagherazzi, S., Kirwan, M.L., Mudd, S.M., Guntenspergen, G.R., Temmerman, S., D’Alpaos, A., Koppel, J., Rybczyk, J.M., Reyes, E., Craft, C., others, 2012. Numerical models of salt marsh evolution: Ecological, geomorphic, and climatic factors. Rev. Geophys. 50.

Finotello, A., Lanzoni, S., Ghinassi, M., Marani, M., Rinaldo, A., D’Alpaos, A., 2018. Field migration rates of tidal meanders recapitulate fluvial morphodynamics. Proc. Natl. Acad. Sci. 115, 1463 1468. https://doi.org/10.1073/pnas.1711330115

Ganju, N.K., Defne, Z., Kirwan, M.L., Fagherazzi, S., D’Alpaos, A., Carniello, L., 2017. Spatially integrative metrics reveal hidden vulnerability of microtidal salt marshes. Nat. Commun. 8. https://doi.org/10.1038/ncomms14156

Gonneea, M.E., Maio, C.V., Kroeger, K.D., Hawkes, A.D., Mora, J., Sullivan, R., Madsen, S., Buzard, R.M., Cahill, N., Donnelly, J.P., 2019. Salt marsh ecosystem restructuring enhances elevation resilience and carbon storage during accelerating relative sea-level rise. Estuar. Coast. Shelf Sci. 217, 56-68. https://doi.org/10.1016/j.ecss.2018.11.003 
Gonneea, M.E., O’Keefe Suttles, J.A., Kroeger, K.D., 2018. Collection, analysis, and age-dating of sediment cores from salt marshes on the south shore of Cape Cod, Massachusetts, from 2013 through 2014. US Geol. Surv. Data Release Httpsdoiorg105066F7H41QPP.

Harshberger, J.W., 1909. The Vegetation of the Salt Marshes and of the Salt and Fresh Water Ponds of Northern Coastal New Jersey. Proc. Acad. Nat. Sci. Phila. 61, 373-400.

Hopkinson, C.S., Morris, J.T., Fagherazzi, S., Wollheim, W.M., Raymond, P.A., 2018. Lateral Marsh Edge Erosion as a Source of Sediments for Vertical Marsh Accretion. J. Geophys. Res. Biogeosciences 123, 2444-2465. https://doi.org/10.1029/2017JG004358

Howes, N.C., FitzGerald, D.M., Hughes, Z.J., Georgiou, I.Y., Kulp, M.A., Miner, M.D., Smith, J.M., Barras, J.A., 2010. Hurricane-induced failure of low salinity wetlands. Proc. Natl. Acad. Sci. 107, 14014-14019. https://doi.org/10.1073/pnas.0914582107

Johnston, M.E., Cavatorta, J.R., Hopkinson, C.S., Valentine, V., 2003. Importance of metabolism in the development of salt marsh ponds. Biol. Bull. 205, 248-249.

Kesel, R.H., Smith, J.S., 1978. Tidal creek and pan formation in intertidal salt marshes, Nigg Bay, Scotland. Scott. Geogr. Mag. 94, 159-168. https://doi.org/10.1080/00369227808736403

Kirwan, M., Temmerman, S., 2009. Coastal marsh response to historical and future sea-level acceleration. Quat. Sci. Rev., Quaternary Ice Sheet-Ocean Interactions and Landscape Responses 28, 18011808. https://doi.org/10.1016/j.quascirev.2009.02.022

Kirwan, M.L., Murray, A.B., 2008. Tidal marshes as disequilibrium landscapes? Lags between morphology and Holocene sea level change. Geophys. Res. Lett. 35, L24401. https://doi.org/10.1029/2008GL036050

Kirwan, M.L., Murray, A.B., 2007. A coupled geomorphic and ecological model of tidal marsh evolution. Proc. Natl. Acad. Sci. 104, 6118-6122. https://doi.org/10.1073/pnas.0700958104

Kirwan, M.L., Murray, A.B., Boyd, W.S., 2008. Temporary vegetation disturbance as an explanation for permanent loss of tidal wetlands. Geophys. Res. Lett. 35, n/a-n/a. https://doi.org/10.1029/2007GL032681

Koop-Jakobsen, K., Gutbrod, M.S., 2019. Shallow Salt Marsh Tidal Ponds-An Environment With Extreme Oxygen Dynamics. Front. Environ. Sci. 7. https://doi.org/10.3389/fenvs.2019.00137

Larsen, L.G., 2019. Multiscale flow-vegetation-sediment feedbacks in low-gradient landscapes. Geomorphology 334, 165-193. https://doi.org/10.1016/j.geomorph.2019.03.009

Leonardi, N., Ganju, N.K., Fagherazzi, S., 2016. A linear relationship between wave power and erosion determines salt-marsh resilience to violent storms and hurricanes. Proc. Natl. Acad. Sci. 113, 6468.

Marani, M., Belluco, E., D’Alpaos, A., Defina, A., Lanzoni, S., Rinaldo, A., 2003. On the drainage density of tidal networks. Water Resour. Res. 39, 1040. https://doi.org/10.1029/2001WR001051

Marani, M., D’Alpaos, A., Lanzoni, S., Santalucia, M., 2011. Understanding and predicting wave erosion of marsh edges. Geophys. Res. Lett. 38, L21401. https://doi.org/10.1029/2011GL048995

Marani, M., Lio, C.D., D’Alpaos, A., 2013. Vegetation engineers marsh morphology through multiple competing stable states. Proc. Natl. Acad. Sci. 201218327. https://doi.org/10.1073/pnas.1218327110

Mariotti, G., 2018. Marsh channel morphological response to sea level rise and sediment supply. Estuar. Coast. Shelf Sci. https://doi.org/10.1016/j.ecss.2018.05.016

Mariotti, G., 2016. Revisiting salt marsh resilience to sea level rise: Are ponds responsible for permanent land loss? J. Geophys. Res. Earth Surf. 121, 1391-1407. https://doi.org/10.1002/2016JF003900

Mariotti, G., Canestrelli, A., 2017. Long-term morphodynamics of muddy backbarrier basins: Fill in or empty out? Water Resour. Res. 53, 7029-7054. https://doi.org/10.1002/2017WR020461

Mariotti, G., Kearney, W., Fagherazzi, S., 2016. Soil creep in salt marshes. Geology 44, 459-462.

Mariotti, G., Kearney, W.S., Fagherazzi, S., 2019. Soil creep in a mesotidal salt marsh channel bank: Fast, seasonal, and water table mediated. Geomorphology 334, 126-137. https://doi.org/10.1016/j.geomorph.2019.03.001 
McKee, K.L., Patrick, W.H., Jr., 1988. The relationship of smooth cordgrass (Spartina Alterniflora) to tidal datums: A review. Estuaries 11, 143-151. https://doi.org/10.2307/1351966

Morris, J.T., Barber, D.C., Callaway, J.C., Chambers, R., Hagen, S.C., Hopkinson, C.S., Johnson, B.J., Megonigal, P., Neubauer, S.C., Troxler, T., Wigand, C., 2016. Contributions of organic and inorganic matter to sediment volume and accretion in tidal wetlands at steady state. Earths Future 4, 110-121. https://doi.org/10.1002/2015EF000334

Morris, J.T., Sundareshwar, P.V., Nietch, C.T., Kjerfve, B., Cahoon, D.R., 2002. Responses of coastal wetlands to rising sea level. Ecology 83, 2869-2877. https://doi.org/10.2307/3072022

Nyman, J.A., Carloss, M., Delaune, R.D., Patrick, W.H., 1994. Erosion rather than plant dieback as the mechanism of marsh loss in an estuarine marsh. Earth Surf. Process. Landf. 19, 69-84. https://doi.org/10.1002/esp.3290190106

OCM Partners, 2019. 2013-2014 U.S. Geological Survey CMGP LiDAR: Post Sandy (MA, NH, RI), https://inport.nmfs.noaa.gov/inport/item/49846.

Pethick, J.S., 1974. The distribution of salt pans on tidal salt marshes. J. Biogeogr. 1, 57-62. https://doi.org/10.2307/3038068

Redfield, A.C., 1972. Development of a New England Salt Marsh. Ecol. Monogr. 42, 201-237. https://doi.org/10.2307/1942263

Redfield, A.C., 1965. Ontogeny of a Salt Marsh Estuary. Science 147, 50-55. https://doi.org/10.1126/science.147.3653.50

Schepers, L., Kirwan, M., Guntenspergen, G., Temmerman, S., 2017. Spatio-temporal development of vegetation die-off in a submerging coastal marsh. Limnol. Oceanogr. 62, 137-150. https://doi.org/10.1002/lno.10381

Spivak, A.C., Gosselin, K., Howard, E., Mariotti, G., Forbrich, I., Stanley, R., Sylva, S.P., 2017. Shallow ponds are heterogeneous habitats within a temperate salt marsh ecosystem. J. Geophys. Res. Biogeosciences 122, 1371-1384. https://doi.org/10.1002/2017JG003780

Spivak, A.C., Gosselin, K.M., Sylva, S.P., 2018. Shallow ponds are biogeochemically distinct habitats in salt marsh ecosystems. Limnol. Oceanogr. 63, 1622-1642. https://doi.org/10.1002/lno.10797

van Huissteden, J., van de Plassche, O., 1998. Sulphate reduction as a geomorphological agent in tidal marshes ('Great Marshes' at Barnstable, Cape Cod, USA). Earth Surf. Process. Landf. 23, $223-$ 236. https://doi.org/10.1002/(SICI)1096-9837(199803)23:3<223::AID-ESP843>3.0.CO;2-I

Wasson, K., Ganju, N.K., Defne, Z., Endris, C., Elsey-Quirk, T., Thorne, K.M., Freeman, C.M., Guntenspergen, G., Nowacki, D.J., Raposa, K.B., 2019. Understanding tidal marsh trajectories: evaluation of multiple indicators of marsh persistence. Environ. Res. Lett. 14, 124073. https://doi.org/10.1088/1748-9326/ab5a94

Wilson, C.A., Hughes, Z.J., FitzGerald, D.M., Hopkinson, C., Valentine, V., Kolker, A.S., 2014. Saltmarsh Pool and Tidal Creek Morphodynamics: Dynamic Equilibrium of Northern Latitude Saltmarshes? Geomorphology. https://doi.org/10.1016/j.geomorph.2014.01.002

Wilson, K.R., Kelley, J.T., Croitoru, A., Dionne, M., Belknap, D.F., Steneck, R., 2009. Stratigraphic and Ecophysical Characterizations of Salt Pools: Dynamic Landforms of the Webhannet Salt Marsh, Wells, ME, USA. Estuaries Coasts 32, 855-870. https://doi.org/10.1007/s12237-009-9203-7

Wilson, K.R., Kelley, J.T., Tanner, B.R., Belknap, D.F., 2010. Probing the origins and stratigraphic signature of salt pools from north-temperate marshes in Maine, U.S.A. J. Coast. Res. 1007-1026. https://doi.org/10.2112/JCOASTRES-D-10-00007.1

Wolfe, R.J., 1996. Effects of open marsh water management on selected tidal marsh resources: a review. J. Am. Mosq. Control Assoc. 12, 701-712. 

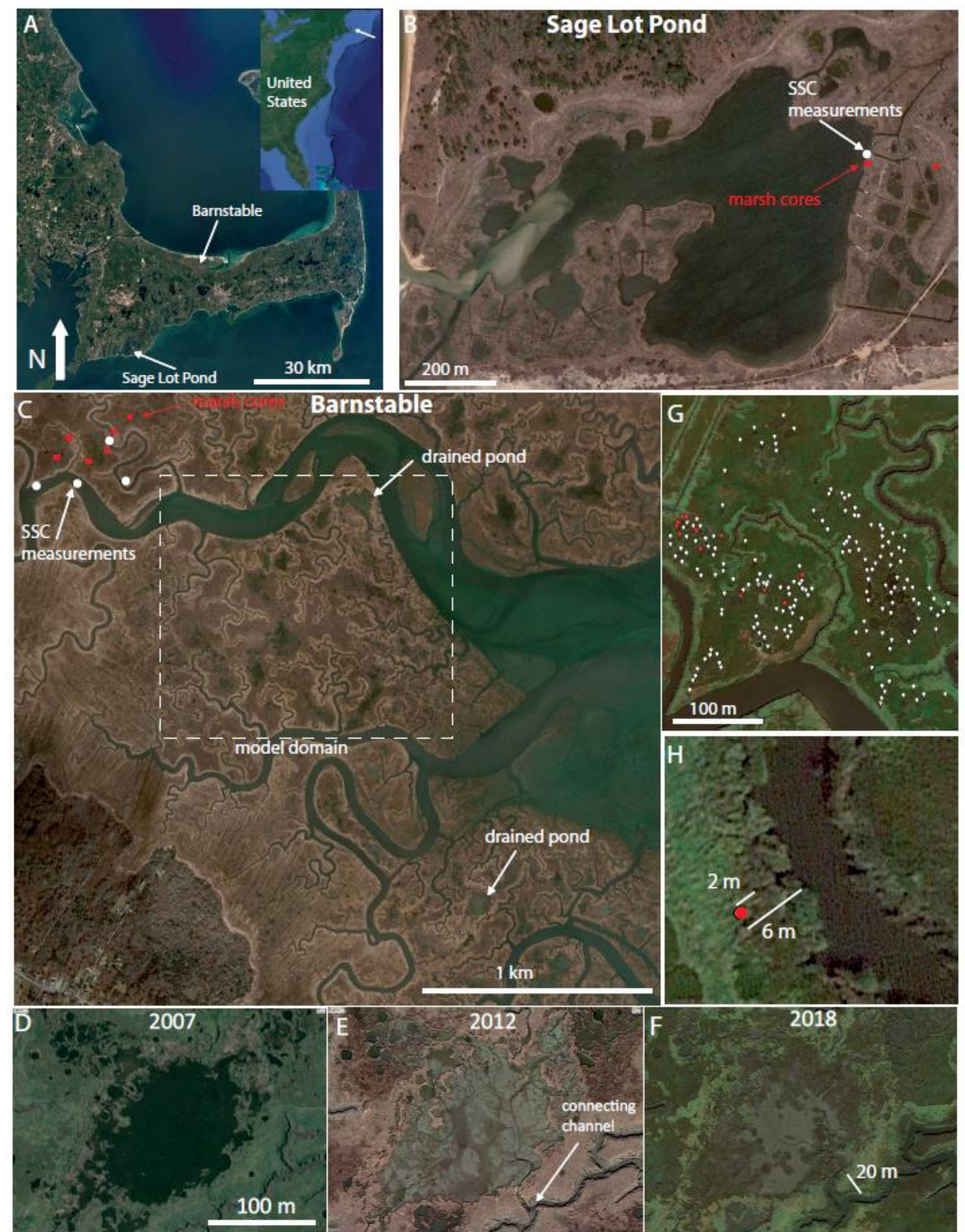

$\mathrm{F}$

2018 
Figure 1. A) Map of the study area including Barnstable marsh and Sage Lot Pond marsh (Massachusetts, USA). B) Sage Lot Pond marsh, C) Barnstable marsh. The dashed rectangle outlines the domain used in the model. The white dots indicate the locations where SSC was measured in triplicates. The red dots indicated the location were cores for vertical accretion were collected. D,E,F) Example of pond reconnection and rapid revegetation (the pond is indicated by the arrow on the bottom right of panel C). G) Location of the surveyed ponds. Red dots indicate ponds surveyed along a transect (showed in Fig. 8), white dots indicate ponds only surveyed at one edge. $\mathrm{H}$ ) Detail of a marsh core collected adjacent to the channel. Images from Google Earth (NASA, USDA) accessed on October 2019.

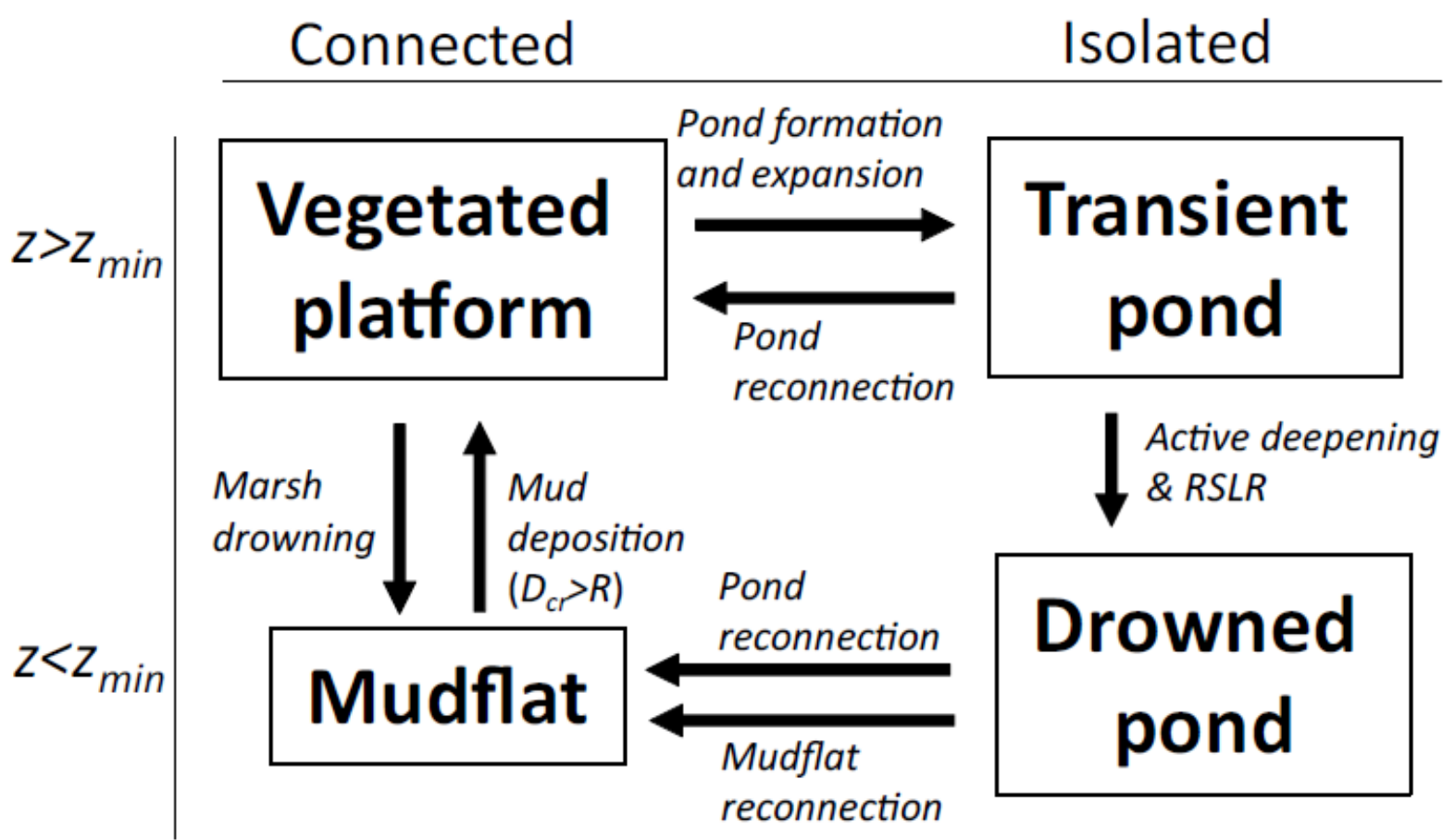

867 Figure 2. Summary schematic of the marsh and pond dynamics and scheme of the various sediment fluxes 868 in the model. Net vertical accretion is equal to the gross vertical deposition minus bank creep and 869 ponding. 


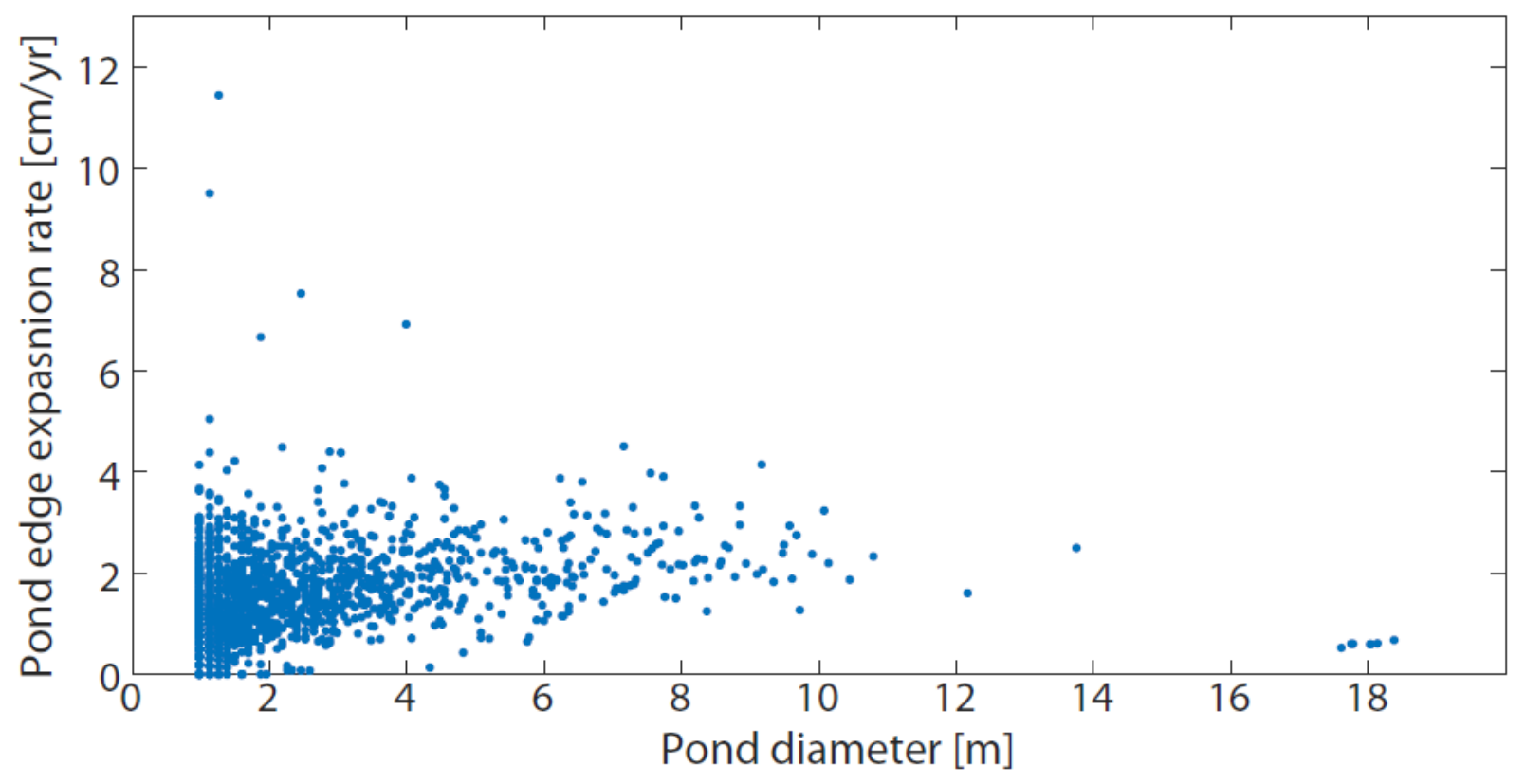

870

871 Figure 3. Measured pond edge expansion rate as the increase of the pond radius through time in

872 Barnstable marsh from 1973 to 2014 as a function of the pond diameter. 

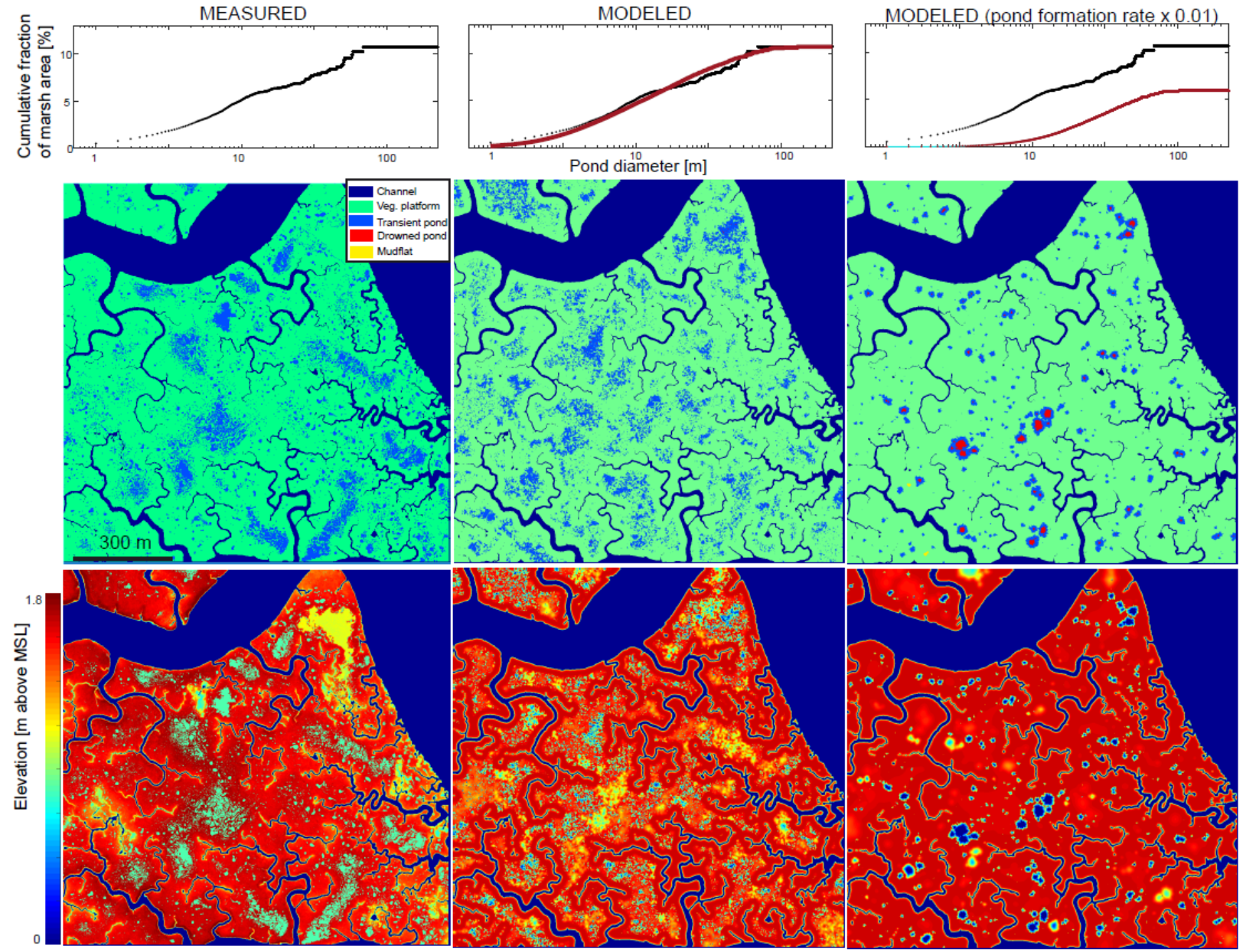

874 Figure 4. A,B,C) Comparison of measured and simulated (at steady state after 1000 years) pond size

875 distribution. A) Measured pond size distribution, showing that the total fraction of pond area is about $10 \%$

876 of the marsh surface. B) Best fit for the parameters $k_{\text {seed }}$ and $k_{\text {exp. }}$ C) Model results for the case in which

$877 k_{\text {seed }}$ is decreased by a factor 100. D,G) Measured pond spatial distribution and elevation E,F,H,I) Model

878 snapshot after 1000 years showing the pond spatial distribution and the elevation (as the last datapoint in

879 Fig. 6). 

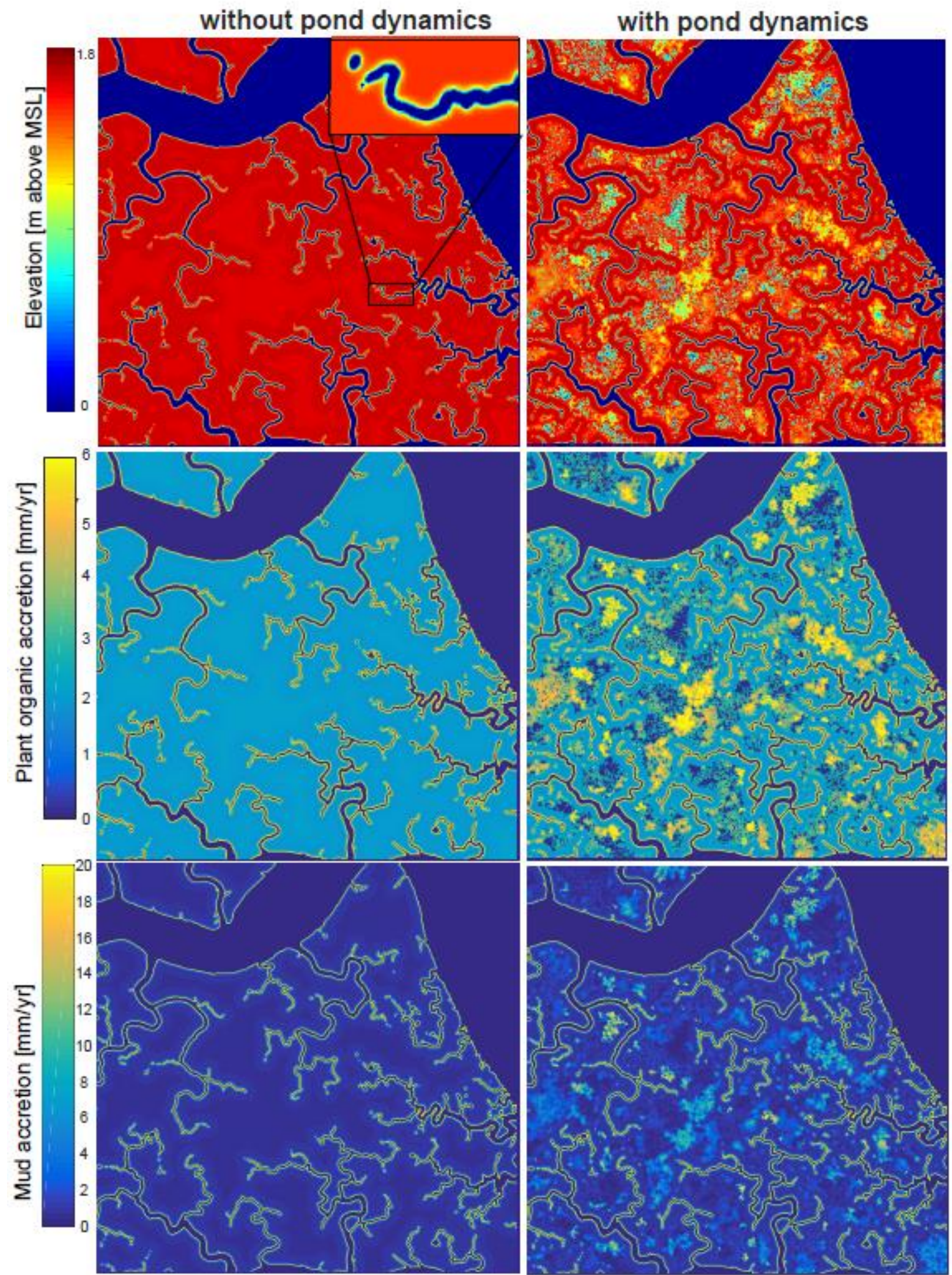
Figure 5. Vertical accretion rate by in situ plant production and by mud accumulation for the case with and without pond dynamics calculated at year 1000 (as the last datapoint in Fig. 6). The inset in the top

884 left panels shows the detail of the low-marsh adjacent to a channel.
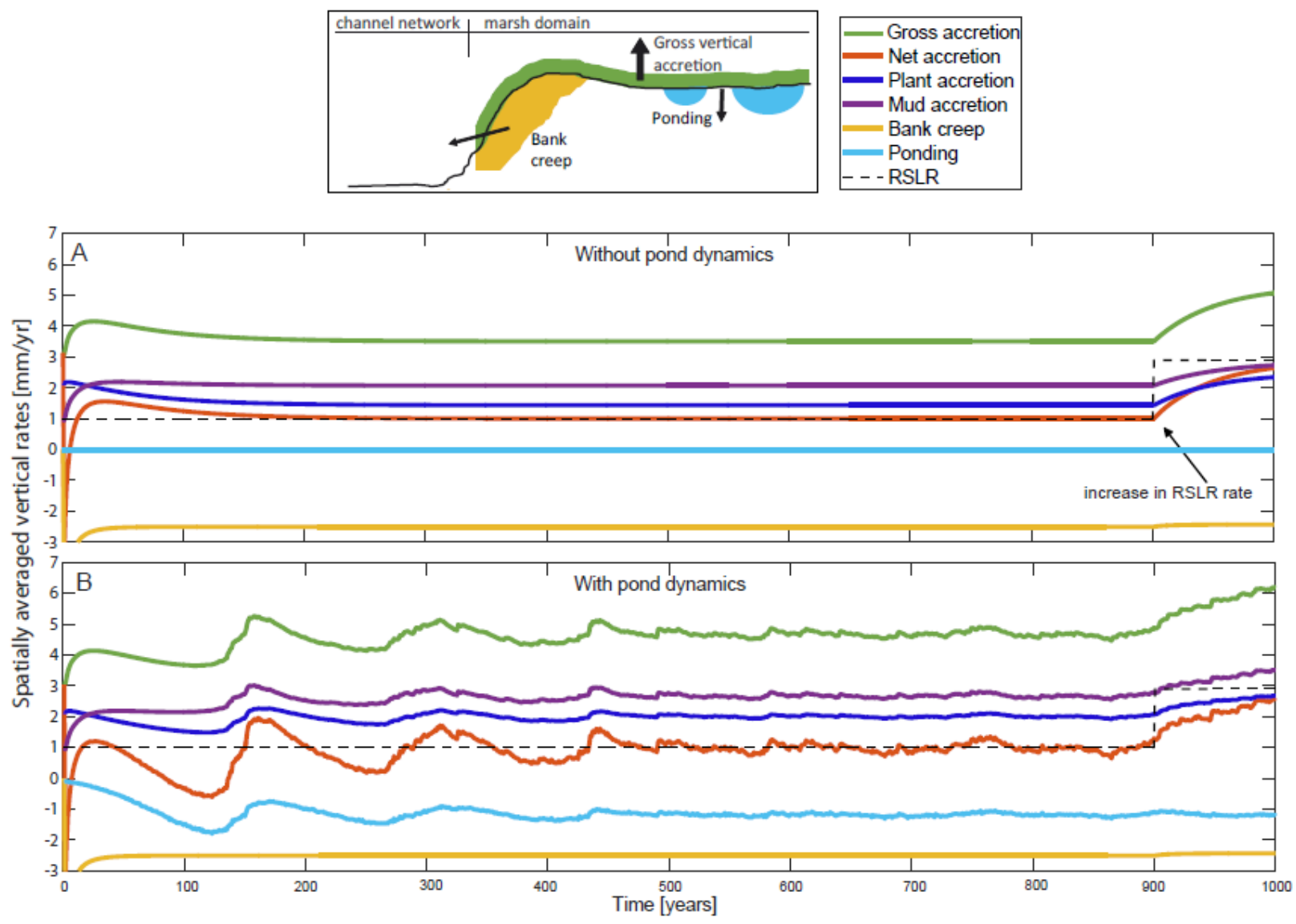

887 Figure 6. Reconstructed time series of spatially-averaged elevation change for Barnstable marsh, comparing the case without ponds dynamics (A) and with pond dynamics (B). Gross accretion is the sum of plant and mud accretion. Net accretion is the gross accretion minus ponding and bank creep. Note that during the first $\sim 500$ years the marsh is equilibrating from the initial conditions without ponds. 

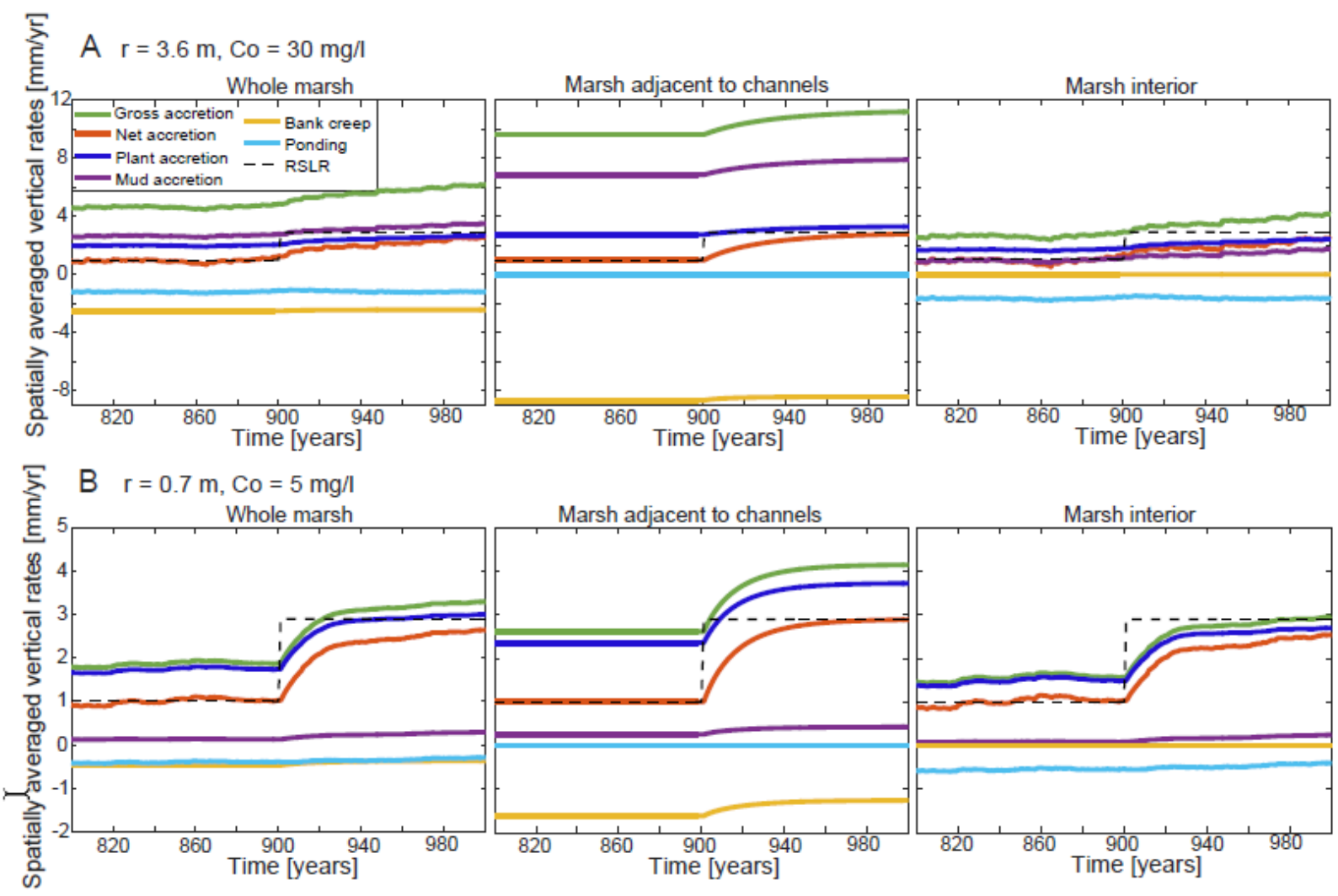

C $\mathrm{r}=3.6 \mathrm{~m}, \mathrm{Co}=30 \mathrm{mg} / \mathrm{l}$
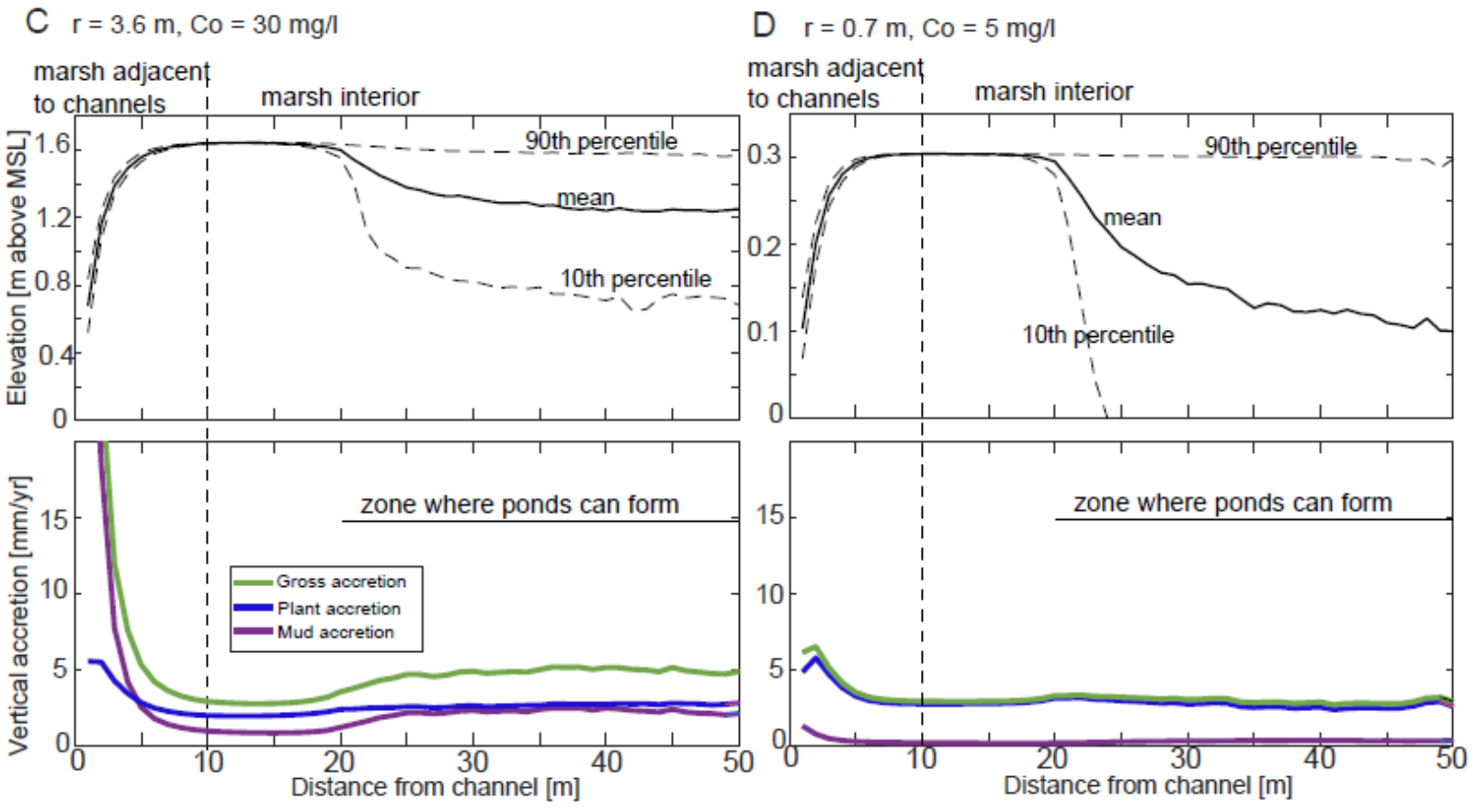

893 Figure 7. A,B) Spatially-averaged elevation change during the transition from $R=1 \mathrm{~mm} / \mathrm{yr}$ to $\mathrm{R}=2.9$

$894 \mathrm{~mm} / \mathrm{yr}$ (as in Fig. 6B), considering the whole marsh area, the area adjacent to channels, and the marsh 
895 interior. Note that in the marsh interior the bank creep is zero. C,D) Snapshot at year 1000 showing the 896 how the vertical accretion varies rapidly with the distance from the channel network. A,C) Conditions 897 representing Barnstable marsh $\left.\left(r=3.6 \mathrm{~m}, C_{o}=30 \mathrm{mg} / \mathrm{l}\right), \mathrm{B}, \mathrm{D}\right)$ Conditions representing Sage Lot Pond $898 \operatorname{marsh}\left(r=0.7 \mathrm{~m}, C_{o}=5 \mathrm{mg} / \mathrm{l}\right)$.
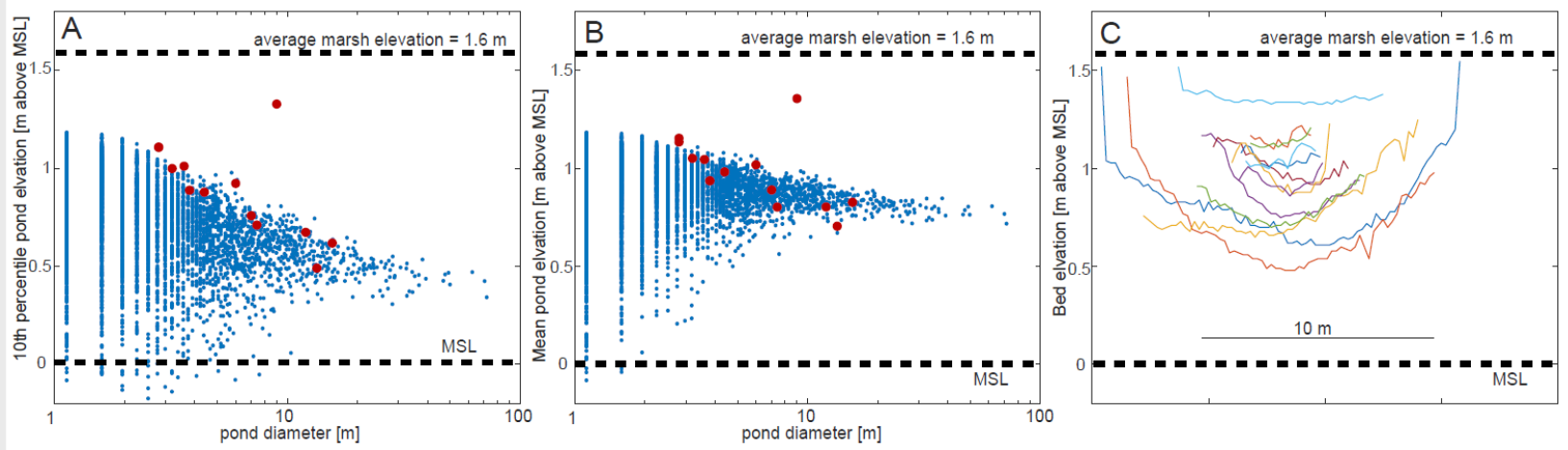

900 Figure 8. A,B) Modeled $10^{\text {th }}$ percentile (A) and mean (B) pond elevation as a function of pond size. The

901 blue dots are the individual points from the model, the red dots are the survey of the 13 ponds in

902 Barnstable marsh. C) Cross sections of the 13 ponds surveyed in Barnstable marsh (see Fig 1G). 

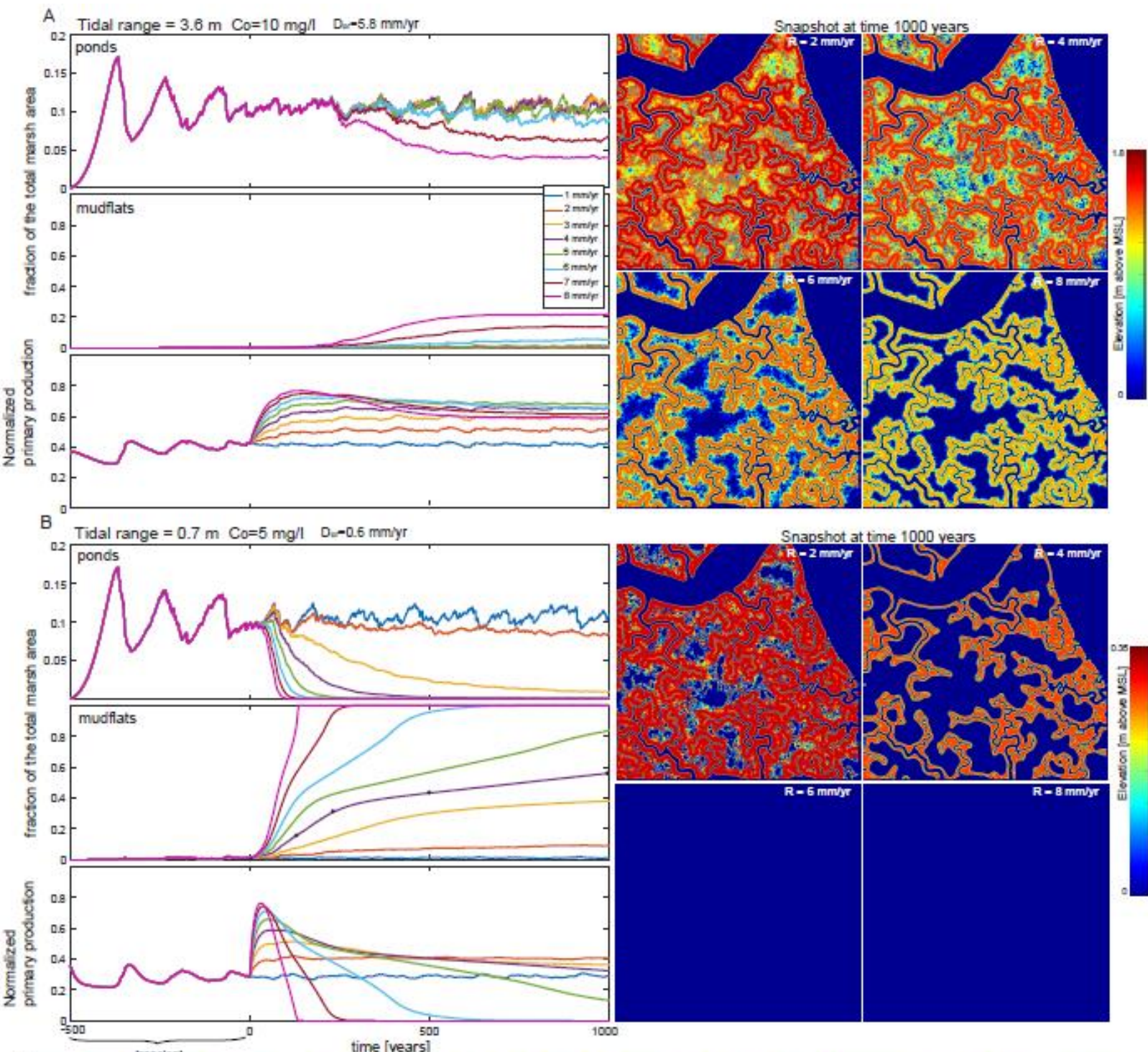

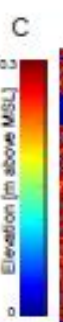
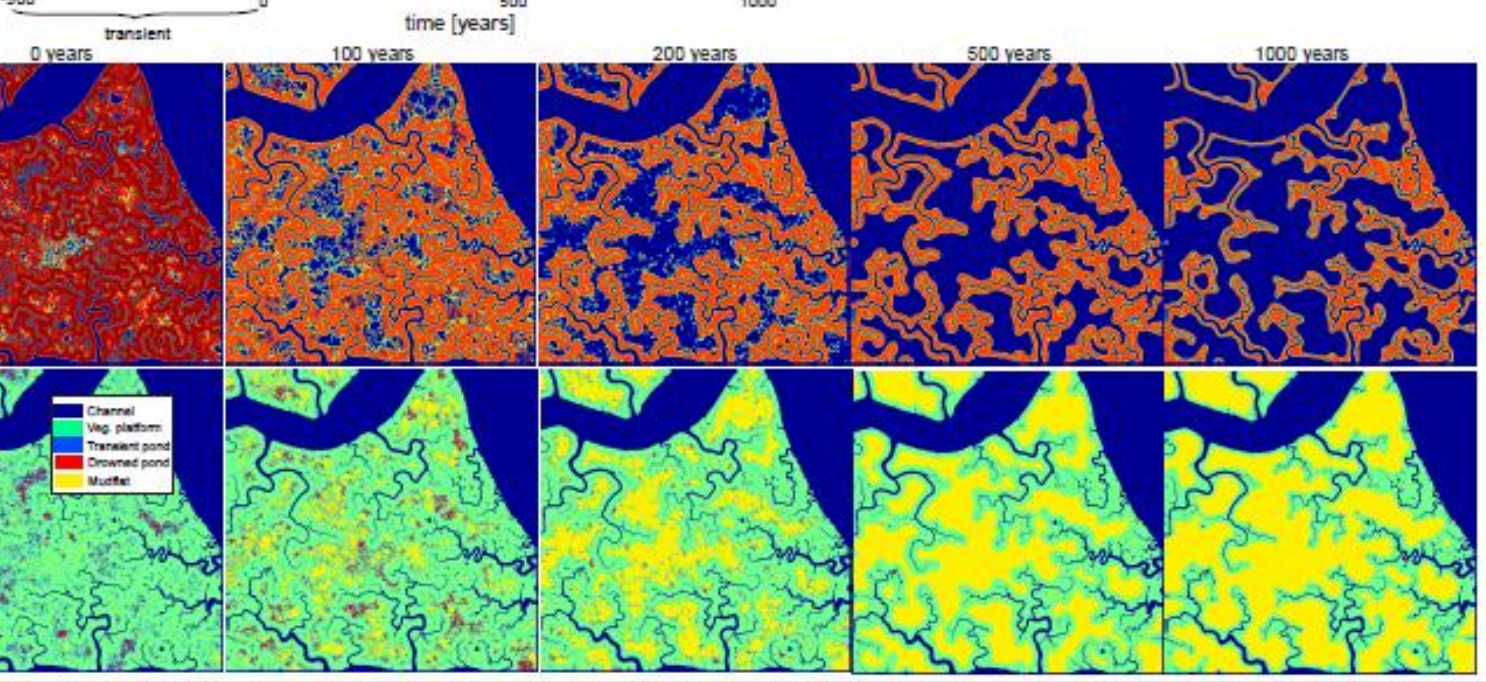
Figure 9. A,B) Amount of pond and mudflat area through time for different RSLR rates for the case of

905 Barnstable marsh $(r=3.6 \mathrm{~m})$ with a reduced sediment supply $\left(C_{o}=10 \mathrm{mg} / \mathrm{l}\right)(\mathrm{A})$, and for the case of Sage

906 Lot Pond marsh ( $r=0.7 \mathrm{~m}$ and $\left.C_{o}=5 \mathrm{mg} / \mathrm{l}\right)(\mathrm{B})$. The normalized primary production is calculated averaging

907 the plant primary production divided by the maximum primary production (which is attained when the

908 marsh is at the elevation optimum). The normalized primary production initially increases because the

909 marsh attains a lower elevation but subsequently decreases when the pond area (whose primary

910 production is assumed to be zero) increases. C) Snapshots of marsh configurations at different times (as

911 indicated by the black dots in panel B) for the case of Sage Lot Pond marsh with $R=4 \mathrm{~mm} / \mathrm{yr}$.

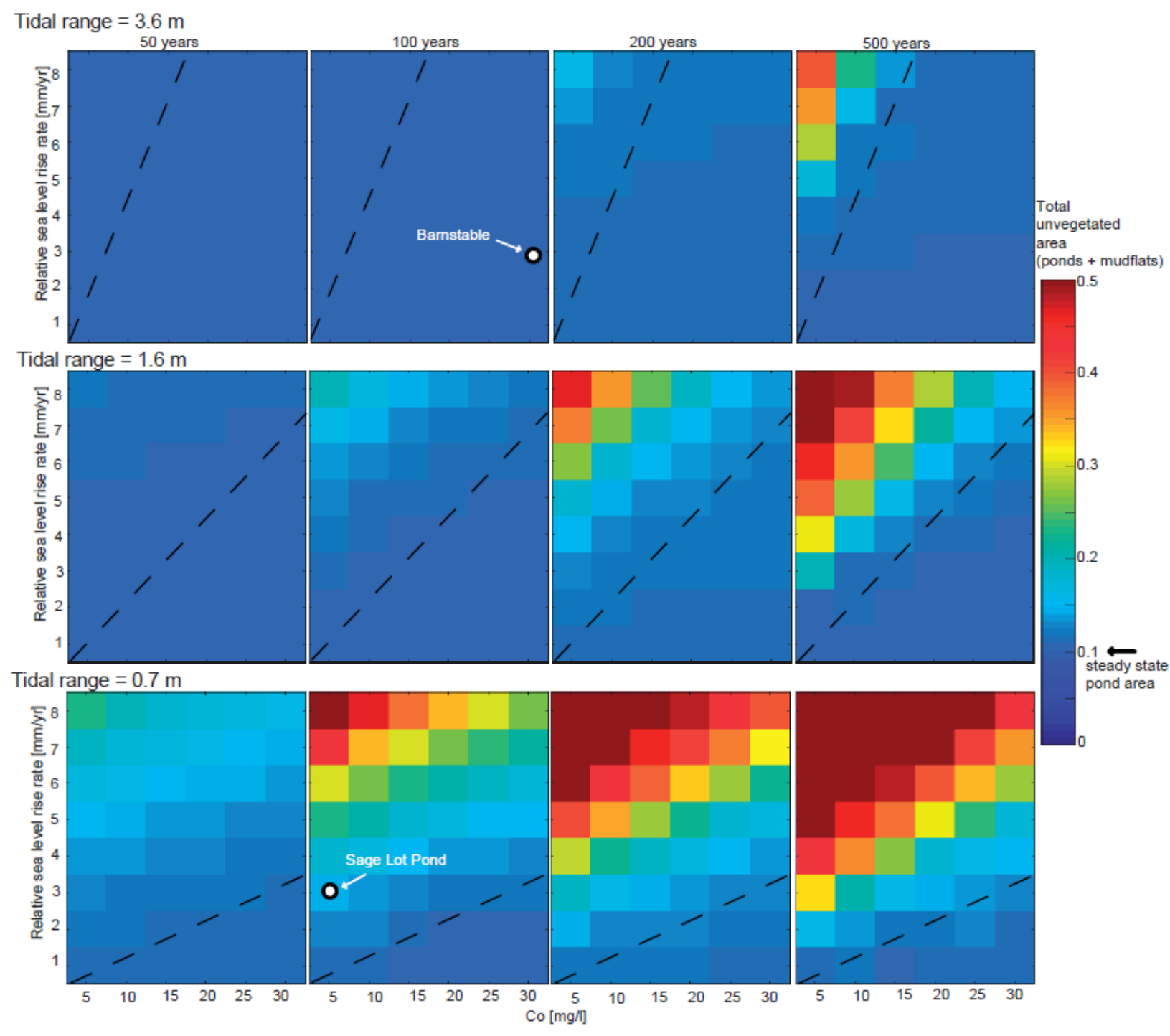


913 Figure 10. Predictions of total unvegetated area (ponds + mudflats) at different time intervals after the

914 increase in RSLR rate. The dashed lines indicate the threshold between pond recovery and pond runaway

915 regime using the lumped pond model of Mariotti (2018), with $R=D_{c r}=\alpha C_{o} r /\left(2 T \rho_{m}\right)$. The comparison with

916 Barnstable and Sage Lot Pond marsh is made assuming that the increase in relative sea level rise rate

917 started about 100 years ago at the beginning of the $20^{\text {th }}$ century.

Table 1. Sediment accretion rates measured on $1 \mathrm{~cm}$ sediment core intervals in Barnstable (measured for this work) and Sage Lot Pond marshes (Gonneea et al., 2019, 2018).

921

922

\begin{tabular}{|l|l|}
\hline Site & $\begin{array}{l}\text { Sediment accretion rate } \\
\mathbf{( 1 9 0 0 ~ t o ~} \mathbf{2 0 1 8}) \mathbf{~ m m} / \mathbf{y}\end{array}$ \\
\hline Sage Lot Pond & \\
\hline Interior (1 core, 13 intervals) & $1.4 \pm 0.3$ \\
\hline Channel-adjacent (1 core, 27 intervals) & $3.6 \pm 2.0$ \\
\hline Barnstable & \\
\hline Interior (3 cores, 134 intervals) & $5.1 \pm 3.3$ \\
\hline Channel-adjacent (3 cores, 130 intervals) & $4.6 \pm 2.5$ \\
\hline
\end{tabular}

923 Table 2. List of parameters used in the model.

\begin{tabular}{|c|c|c|c|c|}
\hline & Symbol & Description & Value & Reference \\
\hline & $\Delta x$ & Spatial discretization & $1 \mathrm{~m}$ & \\
\hline & $\Delta t$ & Temporal discretization & 1 year & \\
\hline \multirow[t]{4}{*}{$\begin{array}{l}\text { Physical } \\
\text { parameters }\end{array}$} & $C_{o}$ & SSC in channels & $\begin{array}{l}30 \mathrm{mg} / \mathrm{l} \text { or } 5 \\
\mathrm{mg} / \mathrm{l}\end{array}$ & Measured \\
\hline & $\rho_{m}$ & Mud dry bulk density & $650 \mathrm{~kg} / \mathrm{m}^{3}$ & Assumed \\
\hline & $\bar{\beta}$ & $\begin{array}{l}\text { Horizontal decay rate of SSC with } \\
\text { distance from channel network }\end{array}$ & $0.05 \mathrm{~m}^{-1}$ & $\begin{array}{l}\text { (Christiansen et al., } \\
2000)\end{array}$ \\
\hline & $\alpha$ & Fraction of spatially uniform SSC & 0.3 & Assumed \\
\hline
\end{tabular}




\begin{tabular}{|c|c|c|c|c|}
\hline & $r$ & Spring tidal range & $3.6 \mathrm{~m}$ or $0.7 \mathrm{~m}$ & $\begin{array}{l}\text { NOAA Station } \\
8447930 \text { and } \\
\text { Station } 8447241\end{array}$ \\
\hline & $\Delta r$ & Spring-neap variability & $0.05 r$ & NOAA \\
\hline & $T$ & Tidal period & $12.5 \mathrm{hr}$ & NOAA \\
\hline & $R$ & Relative Sea Level Rise rate & $2.9 \mathrm{~mm} / \mathrm{yr}$ & NOAA \\
\hline & $\mu$ & Soil creep diffusivity & $0.1 \mathrm{~m}^{2} / \mathrm{yr}$ & $\begin{array}{l}\text { (Mariotti et al., } \\
\text { 2019) }\end{array}$ \\
\hline \multirow{3}{*}{$\begin{array}{l}\text { Vegetation } \\
\text { parameters }\end{array}$} & $z_{\min }$ & Min elevation for vegetation & 0 & Assumed \\
\hline & $z_{\max }$ & Max elevation for vegetation & $r / 2$ & Assumed \\
\hline & $D_{p M A X}$ & Max in-situ organic deposition & $6 \mathrm{~mm} / \mathrm{yr}$ & Assumed \\
\hline \multirow[t]{5}{*}{$\begin{array}{l}\text { Pond } \\
\text { Parameters }\end{array}$} & $k_{\text {seed }}$ & Pond formation rate & $\begin{array}{l}4 \cdot 10^{-4} \\
\text { \#ponds } / \mathrm{m}^{2} / \mathrm{yr}\end{array}$ & Calibrated \\
\hline & $k_{\text {exp }}$ & Pond expansion rate & $0.015 \mathrm{~m} / \mathrm{yr}$ & Measured \\
\hline & $L$ & Drainage influence length & $20 \mathrm{~m}$ & Measured \\
\hline & $Y_{\text {pond }}$ & Max initial depth of new ponds & $0.25\left(z_{\max }-z_{\max }\right)$ & Calibrated \\
\hline & $P_{\text {deepening }}$ & Active deepening of ponds & $3 \mathrm{~mm} / \mathrm{yr}$ & Calibrated \\
\hline
\end{tabular}

